\title{
Torture, Necessity and Existential Politics
}

\author{
Christopher Kutz†
}

"[I]f there is something worse than accepting slavery, it consists in defending it."

-Bernard Williams, Shame and Necessity

\section{INTRODUCTION \\ THE COSTS OF Rights}

Rights have costs-that is their point. The cost of rights is in the coin of foregone welfare gains. No one minds a claim to a particular right when honoring that right simultaneously enhances welfare. For example, the distinctively modern achievement for speech and conscience has been to demonstrate the consilience of rights protecting those domains with the promotion of a flourishing public and private life. As a result, claims of rights to free speech and conscience are among the most easily accepted in U.S. public life. The test of a claim of right, however, comes not when its exercise serves the public good, directly or indirectly, but when it represents a direct hit to welfare. At the level of institutional and philosophical discourse, the United States used to honor the right of individuals to be free of torture in this way. The U.S. government viewed it as justified independently of the costs or gains that might accrue from respecting it. ${ }^{2}$ Now things are different. The current administration of George W. Bush has decided not to pay those costs. Instead, it chooses to use coercive interrogation techniques that would conventionally be thought of as straightforwardly torturous, including water-boarding, false burial, "Palestinian hanging" (where the prisoner is suspended by his arms,

Copyright $(\mathcal{C} 2007$ California Law Review, Inc. California Law Review, Inc. (CLR) is a California nonprofit corporation. CLR and the authors are solely responsible for the content of their publications.

$\dagger$ Professor of Law, Jurisprudence and Social Policy Program, U.C. Berkeley. ckutz@law.berkeley.edu. 1 am grateful for comments and criticism by audiences at Stanford Law School and the University of Toronto Law School; and especially to Larry Alexander, Richard Craswell, Daniel Farber, David Luban, William Ridgway, Markus Wagner, and David Bates.

1. Bernard Williams, Shame and Necessity 111 (1993).

2. 1 echo here David Luban's claims in his paper, Liberalism, Torture, and the Ticking Bomb, in The Torture Debate in America 35 (Karen J. Greenberg ed., 2006) [hereinafter The Torture DEBATE]. I am throughout indebted to his discussion. 
manacled behind his back), being left naked in a cold cell and doused with cold water, and being made to stand for forty hours while shackled to a cell floor. ${ }^{3}$ The override of detainee rights against torture has been justified on grounds of "necessity," i.e., that the welfare cost of observing the right would be too great for the nation rationally to bear.

Legitimacy also has costs. Legitimacy, as normatively understood, refers to the complex conditions under which exercises of institutional power can be justified. While democratic approbation is a central and necessary condition of legitimacy, it is hardly sufficient; populist approval of racist or terroristic policies may provide political protection, but it does not make such exercises normatively justified exercises of power. Nor, for that matter, is direct promotion of social welfare sufficient for legitimacy. If maximizing welfare were sufficient for legitimacy, then any sufficiently effective and benevolent despot could claim legitimacy, substituting reports on the G.D.P. for elections. According to any theory of constitutional democracy - which is to say, under any political theory plausibly relevant to the practices and institutions of the United Statesstate power has legitimacy only when it is exercised on the basis of popular will, through representative institutions, and as constrained by principles of equality, fairness, and humanity. Principled constraint, that is, is a centerpiece of legitimacy. ${ }^{4}$

Justifying the actual conditions of political legitimacy constitutes a time-honored debate of political theory. But while there is substantial disagreement about the best foundation for these conditions, all agree that

3. While there is debate over whether some other well-documented techniques (mild assault, sexual humiliation, terrorization with dogs) legally constitute torture or merely "cruel, inhuman, or degrading" treatment, there is no reasonable debate whether water-boarding (whose point is to introduce fear of death), hanging, and induced hypothermia fit within the definition of torture. See Brian Ross and Richard Esposito, CIA's Harsh Interrogation Techniques Described, ABC NEws, Nov. 18, 2005, http://abcnews.go.com/WNT/lnvestigation/story?id=1322866\&page=1; Michael Hirsh and Mark Hosenball, The Politics of Torture, NEwswEek, Sept. 25, 2006, http://www.msnbc.msn.com/id/14872708/site/newsweek/; Dana Priest, CIA Holds Terror Suspects in Secret Prisons, WASH. Post, Nov. 2, 2005, at Al; Jane Mayer, A Deadly Interrogation, The New YORKER, Nov. 14, 2005, at 44, available at http://www.newyorker.com/fact/content/ articles/051114fa_fact.

In addition, the administration has frequently transported detainees to the security services of other nations widely believed to use interrogatory torture in many diffcrent forms. One such noteworthy case involved Maher Arar, a Canadian citizen who, on the basis of faulty intelligence, was detained by the United States while in transit through Kennedy Airport and deported to Syria, where he was apparently kept in a tiny cell and repeatedly beaten until his lack of intelligence value was recognized. The case, the U.S. involvement, and the faulty intelligence underlying it are detailed in the report of the official Canadian inquiry. Arar Commission, Report of Events Relating to Maher Arar (2006), available at http://www.ararcommission.ca/eng/26.htm. For further discussion of the U.S. policy of “extraordinary rendition," see Jane Mayer, Outsourcing Torture, THE NEW YoRKER, Feb. 14, 2005, at 106, available at http://www.newyorker.com/fact/content/?050214fa_fact 6 .

4. See Richard Fallon, Legitimacy and the Constitution, 118 HARVARD L. REv. 1787, 1790-92 (2005) (distinguishing "moral," or normative, legitimacy from sociological and legal conceptions, and noting their interrelations). 
is no disagreement that the conditions are institutionally complex and significantly restrictive. ${ }^{5}$ Continuing efforts by the administration to lobby both the public and Congress for the ClA's ability to deploy coercive interrogation methods (including water-boarding), ${ }^{6}$ coupled with its legal efforts to defend a broad Executive prerogative in matters of military necessity, represents an attempt to pay the costs of legitimacy in two of the three coins of legitimacy, populism and welfare, while putting aside principled constraint. A series of legal memoranda from 2002 created a backdrop of argument for the Executive's "plenary authority" over foreign affairs and "complete discretion" over military manners, free from legislative intrusion into the arena of national security. ${ }^{7}$ Current efforts by the administration to maintain discretionary control over the limits of interrogation policy, as it negotiates new legislation concerning military detainees in the wake of Hamdan v. Rumsfeld, ${ }^{8}$ have to be interpreted against the assertion of ungoverned discretion.

The debates are contemporary and the sentiments are hot. I do not pretend that my own views are cooler than others'. The issues at stake in the debates over the bounds of interrogation and the limits on the Executive go to the heart of national values and identity, as well as national interests. However, a pretense of objectivity would be one thing; analysis is another. My aim in this Essay is to take up the question of torture's justification at both of the levels raised by the infamous (and now withdrawn) Office of Legal Counsel (OLC) memorandum of August 1, 2002, which became widely known as the "Torture memo." Although this Essay is critical of the positions put forward in that memorandum, criticism is not my main point. Instead, I take the positions put forward in the memorandum (and reflected in current political debates) as an opportunity to examine an essentially philosophical question: what is the force of

5. Among many possible sources, see Ronald Dworkin, Freedom's Law, ch. 1 (1997) (arguing that a normatively defensible conception of democracy requires policies implementing substantive equality and broad civil rights); JoHn RawLS, A ThEORY OF Justice (rev. ed. 1999) (arguing that a just state includes a scheme of equal rights, as well as fair opportunity for all to exercise political power)

6. R. Jeffrey Smith \& Josh White, Cheney Plan Exempts CIA From Bill Barring Abuse of Detainees, WASH. Post, Oct. 25, 2005, at Al.

7. Memorandum from Jay S. Bybee, Assistant Attorney Gen., to Alberto R. Gonzales, Counsel to the President, \& William J. Haynes II, Gen. Counsel of the Dep't of Def. (Jan. 22, 2002), p. $1 \mathrm{I}$ (diseussing President's plenary authority), available at http://www.washingtonpost.com/ wp-srv/nation/documents/012202bybee.pdf; see also Memorandum from Jay S. Bybee, Assistant Attorney Gen., RE: Standards of Conduct for Interrogation under I8 U.S.C. $\S \S 2340-2340 \mathrm{~A}$, to Alberto Gonzales, CounseI to the President, (Aug. 1, 2002), p. 33 (arguing that President enjoys complete discretion) [hereinafter Bybee memo], available at http://fll.findlaw.com/news. findlaw.com/wp/docs/doj/bybee80102mem.pdf. The legal memoranda from this period are helpfully collected in THE TorTure Papers: The RoAD to ABu Ghraib (Karen J. Greenberg \& Joshua L. Dratel eds., 2005) [hereinafter The Torture PaPers].

8. I26 S. Ct. 2749 (2006).

9. Bybee memo, supra note 7. 
principle in extremis? If rights have bite only when they impose costs, how can we think about their nature in relation to those costs without simply adding them to the social welfare sum? This Essay aims to clarify these considerations, and so to set limits to necessity's conceptual force.

First, I argue that attention to the concept of necessity as a justification for torture, and especially to the limits of that justification, reveals that we make use in legal and political thought of two very different normative concepts of rights. The first concept serves to impose limits on institutional considerations, while the second is far more sensitive to such considerations. Instances of the former are core human rights protections; instances of the latter are rights of disposition over property. Legal and philosophical arguments purporting to justify torture by reference to necessity betray a failure to grasp these distinctions. ${ }^{10}$

Second, I argue that the Bush administration's theory of Executive power displays striking parallels to the political theory of Carl Schmitt, the German constitutional thinker, who developed an argument about the need for extra-constitutional Executive power in times of existential crisis for the Republic. ${ }^{11}$ Schmitt was uncompromising in his rejection of the modern, post-Hobbesian ideal of the law-governed state, whose fallacy he saw as revealed in times of national emergency. By comparing the administration's subordination of ordinary law to emergency with Schmitt's argument for unlimited Executive power, I mean to show how deeply radical its theory of political legitimacy is, and how subversive it is in undermining a basic precept of liberal political thought and institutional design: that there must be no source of unlimited political authority. As with Schmitt's theory, the administration's theory ostensibly gains Executive effectiveness at the cost of grave dangers of abuse and error. But I also want to argue that both the justification offered by the administration for using torture in specific cases and the justification offered for broad Executive authority commonly misconstrue the force of claims of necessity in these instances. Necessity cannot serve as a justification for overriding rights against torture or congressional authority to dictate constraints on warfare. Taking the points above together, the administration's policy can be seen as rejecting two of the deepest legacies of the Enlightenment: the inviolability of the individual and the subordination of power to principles of right.

Part II sets out the administration's justification of torture under claims of necessity and situates these within positive law. Part III, the heart of the paper, takes up the claim of necessity in ethics, first in relation to the infamous "ticking bomb" example so often put forward to establish a principle of permissibility. The ticking bomb case is a particular example

10. I discuss examples of this confusion below, in Section III.

II. CaRl Schmitr, Legality and Legitimacy 68-74 (Jeffrey Seitzer trans., 2004) 
of a general problem for principle-based ("deontological," in philosophers' jargon), rather than welfare-based (or "utilitarian"), ethics, namely making sense of limits to rights claims without giving up the core of deontological theory. I distinguish here between two different, familiar and ubiquitous conceptions of rights: rights inherently sensitive to necessity claims, and those insensitive - of which, I argue, rights against torture are the primary example. Part IV provides a synopsis of Schmitt's existential model of political authority and develops the parallel to the administration's theory of Executive power. It then argues that both suffer from a similar, devastating weakness, in that both permit the prospect of necessity to defeat the claim of constitutional limits. Questions of Executive power in times of national necessity, like questions of necessity at the individual level, must recognize the force of the two different forms of right. Part V concludes with observations about the role of necessity in political thought.

\section{I}

\section{Micro- and Macro-Necessity as a Criminal Defense to Torture}

As the story is now familiar, I will summarize: In the spring of 2004, the leak of government memoranda creating a legal basis for U.S. personnel to use torture in interrogations was a shock to many outside the administration. The shock lay less in the acknowledgment that the U.S. was deploying torture than in the lawyerly justification of torture, particularly because, despite the erratic and frequently cruel course of actual state practice, the eradication of the moral and legal basis for torture has been one of the defining features of post-Enlightenment liberal politics. This moral and legal evolution began with the early polemics of Voltaire and Beccaria ${ }^{12}$ and continued with the now-twenty-year-oId U.N. Convention against Torture and other Cruel, Inhuman, or Degrading Treatment or Punishment, which has been ratified by sixty-five countries, including all of the most developed nations save Korea. ${ }^{13}$ Against growing international consensus, the U.S. administration made clear in the days immediately following the terrorist attacks of September $\mathrm{II}^{\text {th }}$ that, in Vice President Dick Cheney's words, "we have to work, though, sort of the dark side." 14 With a political go-ahead, the CIA decided to use a number of

12. Voltaire (François Marie Arouet), "Torture," Dictionnaire PhilosophiQue (1764), available at http://www.voltaire-integral.com/Html/20/torture.htm; Cesare Beccaria, "Ch. 16: Of Torture," ON CRIMES AND PUNISHMENTS (Edward D. Ingraham trans., 1778), available at http://www.constitution.org/cb/crim_pun.htm.

13. Convention against Torture and other Cruel, lnhuman, or Degrading Treatment or Punishment, June 26, 1987, 1465 U.N.T.S. 85. The Convention was ratified by the U.S. on April 18, 1988.

14. Interview by Tim Russcrt with Richard Cheney, "Meet the Press" (Sept. 16, 2001) (transcript available at www.whitehouse gov/vicepresident/news-speeches/speeches/vp20010916.html). As Cofer Black, former Director of ClA Counterterrorist Center, subsequently testified to Congress, "All 1 want to say is that there was 'before' $9 / 11$ and 'after' $9 / 11$. After $9 / 11$ the gloves come off." Testimony of 
formerly proscribed interrogation techniques on "high value" interrogees, notably including "water-boarding," which consists of repeated submersion in cold water to create the impression of drowning. ${ }^{15}$ At some point, before or after the interrogations had actually begun, the CIA apparently became worried that its personnel might be subject to the harsh penalties dictated by I8 U.S.C. $\S \S 2340-2340 \mathrm{~A}$, the implementing legislation for the Convention against Torture. Section 2340A authorizes up to twenty years imprisonment for anyone who outside the U.S. "commits or attempts to commit torture," with capital punishment authorized if death results. ${ }^{16}$ Insofar as the statutory definition of torture includes acts "specifically intended to inflict severe physical or mental pain or suffering," which pain or suffering can result from "the threat of imminent death," orders to deploy waterboarding (which by design arouses a sensation of imminent death by drowning) would clearly have focused the minds of U.S. personnel on the consequences of the Torture statute. ${ }^{17}$

Prompted by the CIA's request, the OLC, under the signature of Jay Bybee, provided a memorandum to the White House on August 1, 2002. ${ }^{18}$ This memorandum, which I will call the Bybee memo, made a number of arguments toward several aims. First, it sought to reduce the potential scope of $\S 2340$ to include only the most heinous forms of torture. Second, it sought to suggest a range of complete criminal defenses U.S. personnel could deploy if charged under the statute. Finally, it sought to establish as a principle of constitutional law that $\S 2340 \mathrm{~A}$ could not constitutionally be interpreted to bind the President while exercising his war powers as Commander in Chief. ${ }^{19}$

I am chiefly concerned with the second and third arguments in the memorandum, which I take up in reverse order. After giving its restrictive definition of torture, the memo contemplates the case in which U.S. personnel may be found to have engaged in acts within the scope of the statutory prohibition, namely to have inflicted with specific intent or attempted to inflict severe physical or mental pain or suffering. ${ }^{20}$ It then argues for the claim that "[s]tandard criminal law defenses of necessity and self-defense could justify interrogation methods needed to elicit

Cofer Black to Joint House and Senate Select Intelligence Committee, Sept. 26, 2002, available at http://www.fas.org/irp/congress/2002_hr/092602hlack.html.

I5. Douglas Jehl and David Johnston, C.I.A. Expands its Inquiry into Interrogation Tactics, N.Y. Times, Aug. 29, 2004, at A I; Mark Danner, Abu Ghraib: The Hidden Story, N.Y. Rev. of Books, Oct. 7, 2004, available at $\mathrm{http}: / / \mathrm{www}$. nybooks.com/articles/17430.

16. 18 U.S.C. $\$ 2340 \mathrm{~A}(\mathrm{a})$.

I7. 18 U.S.C. $\$ 2340(1),(2)(c)$.

I8. Byhee memo, supra note 7.

19. I discuss the Bybee memos at greater length, and the specific role of the OLC lawyers, in two papers: The Lawyers Know Sin, in The ToRTure DeBate, supra note 2, at 24l-46; and Causeless Complicity: The Case of the OLC Lawyers, CRIM. L AND PHIL. (forthcoming 2007).

20. Bybee memo, supra note 7 , at 27. 
information to prevent a direct and imminent threat to the United States and its citizens."21 As the memo rightly describes the Model Penal Code (MPC), necessity will justify a defendant in violation of a law when he or she engages in conduct that the actor "believes to be necessary to avoid a harm or evil to himself or to another," provided that violating the norm is necessary to avoid a "harm or evil" that is "greater than that sought to be prevented by the law defining the offense charged," but only so long as there is no specific legislation or "legislative purpose" to exclude the justification. ${ }^{22}$ Necessity justifies otherwise criminal acts against subjects who do not directly pose a threat to the actor. In its paradigm applications, for example, necessity justifies sailors jettisoning cargo to save their ship or a hiker breaking into a cabin to escape a sudden storm. ${ }^{23}$ Necessity is, therefore, a potential justification for the situation under consideration in the memo: the decision whether to torture a subdued detainee, who may have information that may help avert a threat that may arise.

Specifically, the claim would have to be used to justify an interrogation technique believed to be the sole effective means of avoiding yet worse harms. On its face, then, necessity might provide a good fit for the interrogation practices in question. However, and somewhat peculiarly, the memo explores a much less suitable defense as well: other-defense. ${ }^{24}$ The claim is peculiar because other-defense justifies the use of force against an adversary who is himself deploying unlawful force against the defender. ${ }^{25}$ As the memo itself acknowledges, a confined and subdued interrogee is not, by hypothesis, actually deploying unlawful deadly force against the interrogator or another, even if the interrogee might reasonably be believed to be planning to do so, or to have already set such force in motion. By its very terms then, the common-law defense of other-defense would seem inapplicable. Indeed, the only doctrinal support mustered by the Bybee memo for the use of "defensive" force against a non-threatening actor is a single law review article-an article which, in fact, asserts that while "the literal law of self-defense is not available to justify" torturing a "terrorist" who, while not presently attacking, has "culpably caused" the conditions that threaten the torturer, a moral principle may be derived

21. Id. at 39

22. Model Penal Code $\S 3.02(1)$, (1)(a) [hereinafter MPC]. More exactly, $\S 3.02(1)$ provides for a dcfense whenever a defendant believes, even unreasonably, that he or she is in a situation of necessity. Under $\S 3.02(2)$, however, reckless or negligent defendants can still be liable for crimes for which recklessness or negligence suffice for culpability. The net result approximates the position at common law, according to which only a reasonable belief as to the necessity of the act serves as a defense.

23. Model Penal Code and Commentaries $\S 3.02$, cmt. 1, at 9-10 [hereinafter MPC Commentaries].

24. Bybec mcmo, supra note 7, at 33-34.

25. MPC $\S 3.04(1) ; 1$ Wayne R. LaFave \& Austin W. Scott, JR., Substantive Criminal LAW $\S 5.7$ at 649 (1986 \& 2002 Supp.). 
analogically from the situation countenanced by the law. ${ }^{26}$ Even this moral principle offers little actual support insofar as it is premised on the claim that the interrogee has "culpably caused" the threatening condition. Putting aside the case where the interrogee might simply know about such conditions but not want to disclose them (whether out of fear or enmity), the status as culpable causer is frequently what the interrogation must discover, not its premise. The non-metaphorical case of defense against an actual attacker doesn't lend itself to such doubts, except in the limiting (and here inapplicable) case where a gesture might be ambiguous between threat and innocence. Thus, the conditions that might make other-defense even metaphorically appropriate would be very unlikely to obtain.

Given the lack of doctrinal support for the position, one can best charitably read the Bybee memo's invocation of other-defense as resting on two reasons. First, the case law of self-defense, unlike the case law of necessity, provides authority for the use of force against others. Second, self- and other-defense claims can be seen as a specific case of the broader necessity defense. As the memo correctly states, the core of self- or otherdefense lies in the defender's belief that such force is "immediately necessary" to avoid the harm posed by someone presenting a direct and imminent threat of serious bodily harm to oneself or another. ${ }^{27}$ Necessity grounds the permission to use otherwise impermissible force.

So the argument for the justifiability of torture as a matter of criminal law must stand or fall with the force of the general necessity defense and its limitations. Let us return, then, to the general justificatory element of necessity, specifically, the "necessity" of deploying force in order to prevent a more serious harm. Taken literally, the defense is limited to cases in which the use of force is the only possible response to the threat and is sure to be an effective response to the threat. Only when the defendant's act is a necessary element of a set of conditions sufficient to avert the harm can it be said that the defendant acted as he must, in order to minimize evil. It cannot, in other words, be necessary to act when one's act will be ineffective, even if, were other conditions in place, it might have been part of a set of conditions sufficient to avert the harm. ${ }^{28}$

In fact, the criminal defense of "necessity" presents much softer constraints than true, logical "necessity" would indicate, in large part because it is applied relative to the actor's beliefs about the threat and its

26. Michael S. Moore, Torture and Balance of Evils, 23 IsR. L. Rev. 280, 323 (1989) (cited by the Bybee memo, supra note 7, at 44).

27. Bybee memo, supra note 7 , at $42-43$ (citing MPC $\$ 3.04$ and LAFAVE \& SCOTT, supra note 25 , at 649).

28. Logically, if "ought implies ean,"--that is, one only has obligations to do what it is possible to do-then "cannot" also implies "not ought." One has no obligation, much less requirement, to do the impossible. My swimming to rescue the drowning swimmer might have been a necessary condition of his being saved, if 1 am the only one within range; but if 1 eannot swim, it is not necessary that 1 try. 
projected alternatives. Under the MPC, actors can assert the defense so long as they believe in the necessity of their acts, both regarding the likelihood of the threat and the effectiveness of the alternatives, even if in fact there is no threat, or the means chosen could not be effective. Thus, the MPC defense protects actors who believe, however unreasonably, in the necessity of their acts. However, the necessity provision also provides for liability for defendants who are reckless or negligent in either bringing about the conditions demanding their response or in assessing the necessity of the response. ${ }^{29}$ The net result, under both common law and the MPC, is that full justification is provided only to actors who reasonably appraise the situation as calling for their violation of the law. ${ }^{30}$ But it should be understood that the subjective extension of the defense, to the reasonable but mistaken defendant, clearly gets its justificatory force from the objective situation where, under the circumstances, the defendant performed an act necessary in fact to avert the greater evil. ${ }^{31}$ Put otherwise, an actor's judgment of necessity can only be exculpatory if, when the factual premises of that judgment are true, the actor really would be justified. If necessity were instead conceived as an excuse, then any belief, however unreasonable, would be sufficient to exculpate. Since common law and the MPC are clear that only reasonable mistake fully exculpates, the underlying principle must be one of objective justification. ${ }^{32}$

Note the slippage in the theory of necessity - a slippage that, as we shall see, plays a role in evaluating the special case of the ticking-bomb hypothetical. The objective situation is posed timelessly, where the antecedent threat can be weighed against the future consequence of the law-breaking response. But in reality, of course, the defense must apply to conduct undertaken before the threat materializes. It is nearly always impossible to know whether the threat really would have been realizedperhaps the attacker would have suddenly run rather than shot, or a rescue

29. MPC $\S 3.02(2)$ states:

When the actor was reckless or negligent in bringing about the situation requiring a choice of harms or evils or in appraising the necessity for his conduct, the justification afforded by this Section is unavailable in a prosecution for any offense for which reeklessness or negligence, as the case may be, suffices to establish culpability.

30. See Wayne R. LaFave, Criminal Law $\$ 10.1$ (d)(3) (4th ed. 2003).

31. The effect of rendering the justification subjective is to include both objeetively unjustified but morally non-culpable actors, and to exelude coincidentally justified but morally eulpable actors. The essentially objeetive character of the justifieation is evident in LaFave and Scott's treatment, and is manifest in the memo, which discusses the defense as providing a genuine justification, and not just exculpation.

32. As LaFave says,

The rationale of the neeessity defense is not that a person, when faced with the pressure of circumstances of nature, lacks the mental element which the erime in question requires. Rather, it is this reason of public policy: the law ought to promote the achievement of higher values at the expense of lesser values, and sometimes the greater good for society will be accomplished by violating the literal language of the criminal law.

LAFAVE, supra note 30 , at 524. 
ship might have appeared on the horizon, had defendants waited a few more days. ${ }^{33}$ Furthermore, it is almost always impossible for anyone, let alone the defendant, to know in advance whether the use of force will be effective in meeting the threat. Defendants cannot perfectly anticipate the consequences of their acts, but must instead calculate the expected value of their responses in relation to the expected disvalue of the threatened harm. This is an elementary point, but, when understood, it means that in practice actual "necessity" almost never exists. The defense must instead be read to justify the rather oxymoronic category of "probabilistic necessity": the defense justifies extralegal acts when and only when they are highly likely to avert a virtually certain threat, and it is also highly likely that there are no other options. The normative force of necessity resides in the epistemic requirement of high certainty - a requirement necessary to foreclose the possibility of defendants taking extremely low-probability gambles on high-payoff results. ${ }^{34}$ In sum, it is a form of cost-benefit analysis that justifies criminal acts when, given only two options, good consequences outweigh the bad, restricted to some indeterminate extent by a requirement of substantial certainty as to the relevant gambles. ${ }^{35}$

In principle, then, the Bybee memo looks as though it stakes out a defensible legal position: if the expected value of information extracted through torture is high enough to outweigh the expected disvalue of the materialized threat about which intelligence is sought, then torture could be justified. This is a much broader justification than that offered by self- or other-defense, for necessity would seem, in principle, to justify the use of torture against any person whose suffering might thereby motivate another to talk or otherwise impede the growing threat. And while an official government document asserting the applicability of the necessity defense to torture is remarkable in modern criminal law, it is not unprecedented, as the Israeli Supreme Court has also famously mooted application of the defense. ${ }^{36}$ But the most remarkable feature of the Bybee memo is the way it

33. See the famous example of Regina v. Dudley \& Stephens, 14 Q.B.D. 273 (1884) (upholding rejection of defense of necessity by eannibalistic sailors, in part because the sailors "might possibly have been picked up next day by a passing ship; they might possibly not have been picked up at all.") (Lord Coleridge, C.J.).

34. At common law, self-defenders are not even held to such a high standard. The majority of states do not require defenders to choose to retreat, even when they can do so in safety, and one need never retreat from a home. See LAFAve \& ScotT, supra note $25, \S 10.4(\mathrm{f})$.

35. Treatises, the MPC Commentaries, and the Bybee memo straightforwardly identify the defense as having utilitarian valuc. See MPC Commentaries, supra note 23, §3.02, cmt. 3; LAFAvE, supra note 30, §10.1(a); Bybee memo, supra note 7, at 40 .

36. HCJ 6536/95 Hat'm Abu Zayda v. The General Security Scrvice [1999] (consolidated with other cases), available at http://www.law.yale.edu/documents/pdf/ Public_Committee_Against_Torture.pdf (unofficial translation) (denying the State Security Service standing permission to deploy physically abusive, inhumane interrogation techniques in administratively-defined "ticking bomb" circumstances, but establishing that defendants might, ex post, claim a necessity defense for using such tactics). 
embeds the discussion of act-specific necessity, as a criminal law doctrine, within an effectively wholesale conception of necessity. For the most striking claim in the Bybee memo arises even before canvassing the criminal law defenses. According to the memo, "We have also demonstrated that Section 2340A, as applied to interrogations of enemy combatants ordered by the President pursuant to his Commander in Chief power would be unconstitutional. ${ }^{937}$ Thus, in addition to the micronecessity claim of the criminal law defense, the Bybee memo also invokes what I will call a macro-necessity claim in its constitutional argument. According to the memo,

[T] ] Department of Justice could not enforce Section 2340A against federal officials acting pursuant to the President's constitutional authority to wage a military campaign. ... Within the limits that the Constitution itself imposes, the scope and distribution of the powers to protect national security must be construed to authorize the most efficacious defense of the nation and its interests in accordance "with the realistic purposes of the entire instrument." 38

The memo argues that "intelligence operations, such as the detention and interrogation of enemy combatants and leaders, are both necessary and proper for the effective conduct of a military campaign," and that the Constitution grants the power to wage such campaigns exclusively to the Executive. ${ }^{39}$ In other words, the President can authorize his agents to use any ordinarily extra-legal means when he judges such means appropriate (the real sense of "necessary and proper") to meet a military objective.

On its face, this is an extraordinarily generous amount of power, which does not even require a state of war, but only the context of a "national security" concern. The position can be read as a broad form of necessity justification. According to the Bybee memo, the governmental structure under the Constitution is itself conceived functionally, an instrument for preserving the "security of the United States," and the President's role within that scheme is defined derivatively, as necessary to effect the goal of security. ${ }^{40}$ Thus, extralegal policies are justified immediately as exercises of instrumentally justified discretion.

The Bybee memo has come under severe attack as an interpretation of criminal Iaw. According to critics, its legal reasoning ranges from

37. Bybee memo, supra note 7 , at 39 .

38. Id. at 36-37 (internal citations omitted).

39. Id. at 39 .

40. "The text, structure and history of the Constitution establish that the Founders entrusted the President with the primary responsibility, and therefore the power, to ensure the security of the United States in situations of grave and unforeseen emergencies." Id. at 37. 
unconvincing to ludicrous. ${ }^{41}$ As David Luban elaborates, the memo derives its definition of torture from a health statute. ${ }^{42}$ It fails to acknowledge the total absence of federal or state case law supporting its assertion that the necessity defense might apply to intentional acts of violence under color of law outside the narrow contexts of self-defense or restraint of a fugitive (as well as the fact that the necessity defense has only been recognized in federal criminal law in order to be rejected in each case). In order to avoid the contravention of legislative purpose (one of the limiting conditions of the defense), the Bybee memo interprets $\S 2340 \mathrm{~A}$ 's absolute prohibition of torture as, by negative implication, creating statutory space for exceptions governed by necessity. ${ }^{43}$ And finally, as mentioned above, the memo invokes self- and other-defense justifications outside their ordinary context of force used against an active threat, grounding the claim not in doctrine at all, but in a single instance of philosophical argument. ${ }^{44}$

So much for micro-necessity doctrine. The constitutional, macronecessity analysis is similarly thinly sourced. While making the extraordinary claim that statutes cannot be construed, as a matter of constitutional law, to restrain the Commander in Chief's war powers, the

41. David Luban, Liberalism. Torture, and the Ticking Bomb, 91 VA. L. REv. 1425, 1455 (referring to a "near consensus that the legal analysis contained in the Bybee memo was bizarre"). See also Jeremy Waldron, Torture and Positive Law: A Jurisprudence for the White House, 105 Colum. L. REv. 1681 (2005). Critics of the Bybee memo ranged from academics to policymakers, and from the left to the (relative) right, including an influential editorial denunciation by former ClA chief James Woolsey (under Bill Clinton) and Ruth Wedgewood, until then a tireless advocate for the post 9/11 policies of the Bush administration. Ruth Wedgwood and R. James Woolsey, Law and Torture, WALL ST. J., June 28, 2004, at A 10, available at http://www.benadorassoeiates.com/article/5500. Senator John McCain's legislative attempts, through the Detainee Treatment Act of 2005 (Pub. L. No. 109-148, $\S \S 1001-1006$ (2005), becoming Section X of the Department of Defense Authorization Aet of 2006); and the Military Commissions Act of 2006 (Pub. L. No. 109-366, 120 Stat. 2600 (Oct. 17, 2006), Sec. 6(b)), to define the scope of liability for U.S. personnel can also be seen as responses to the new policy on interrogation.

42. The Bybee memo treats a statutory definition of pain severe enough to trigger emergency care health benefits, per 42 U.S.C. $\S 1395 \mathrm{w}-22(\mathrm{~d})(3)(B)$, as defining the threshold above which the infliction of suffering is criminally punished. Bybee memo, supra note 7 , at 6 . The TORTURE DeBate, supra note 2, at 65-67, notes all the flaws in the analysis summarized in this paragraph.

43. Bybee memo, supra note 7, at $41 \mathrm{n} .23$ ("By leaving Section 2340 silent as to the harm done by torture in comparison to other harms, Congress allowed the neeessity defense to apply when appropriatc."). Though the command, "Stop now, right where you are" should be properly interpreted to mean, "Stop where you are ... unless you have a good reason to keep going." It is true that speeding laws, for example, also are eouched in absolute terms yet support necessity justifications. However, there is no plausible canon of statutory construction according to which an unqualified prohibition on torture can be read as a selective permission, when sueh prohibition implements a treaty that, by its terms, specifically proscribes torture's deployment for "such purposes as obtaining from [the victim] or a third person information or a confession, punishing him for an act he or a third person has committed or is suspected of having committed, or intimidating or coercing him or a third person." Convention against Torture, supra note 13, Art. 1.

44. Luban, supra note 2, at 62-65. See also Waldron, Torture and Positive Law, supra note 41, which also takes up the peculiar and disturbing nature of the memo's interpretive approach to positive law. 
Bybee memo fails to cite the principal modern case on legislativeExecutive relations in time of war, Youngstown Sheet \& Tube, which held that President Truman must rely on explicit legislation or a constitutional provision even when acting during wartime on grounds of military necessity. ${ }^{45}$ Nor does the memo mention the contrary constitutional text empowering Congress to "make Rules for the government and regulation of the land and naval forces" and to "discipline" the militias. ${ }^{46}$ In its excursion into original intent, it further relies on extremely exiguous material. For example, the memo quotes Alexander Hamilton's vision for broad national power to "provide for the defence and protection of the community." However, this implies nothing about the specific authority of the President in relation to Congress. ${ }^{47}$ But even if original intent were controlling-the consequence, obviously, of a complex argument in political theory-it is highly implausible that the Framers, who were students of Montesquieu's separation of powers and the English debates on the limits of royal power, would have endorsed such a sweeping view of the Executive's authority. ${ }^{48}$ As Jack Rakove, one of the leading historians of the Founding era, wrote, "[O]n balance there is little evidence that the ratifiers expected either that the president would have the dominant voice in the making of foreign policy or that the Senate would be reduced to acting as a mere check on the executive." 49

45. Youngstown Sheet \& Tube v. Sawyer, 343 U.S. 579 (1952). Youngstown is, of course, the locus of Justice Jackson's famous concurrence, in which he argued:

When the President takes measures incompatible with the expressed or implied will of Congress, his power is at its lowest ebb, for then he can rely only upon his own eonstitutional powers minus any constitutional powers of Congress over the matter. Courts can sustain exclusive presidential control in such a case only by disabling the Congress from aeting upon the subject. Presidential claim to a power at once so conclusive and preclusive must be serutinized with caution, for what is at stake is the equilibrium established by our constitutional system.

Id. at 637-38 (Jackson, J., coneurring). Jaekson's concurring dictum was reasserted, to effect, in Hamdan, 126 S. Ct. at 2774, n. 23.

46. U.S. Const. art. $1, \S 8$, cls. 14, 16. As Richard Posner notes, the framework of the Bybee memo argument (which he attributes to John Yoo) makes little sense: since the President is Commander in Chief in peace as well as war, it cannot be that his status as Commander in Chief precludes congressional regulation of the land and naval forces. RICHARD A. PoSNER, Not a SUICIDE Pact: The Constitution in a Time of National Emergency 67-68 (2006).

47. Bybee memo, supra note 7, at 37 (quoting The Federalist No. 23 (Alexander Hamilton))

48. On the intellectual sources of the political theory of the Framers, including Montesquieu, see Bernard Bailyn's elassic work, The Ideological Origins of the AMERICAN Revolution (1967).

49. Jack N. Rakove, Making Foreign Policy: The View from 1787, in ForeIGN POLICY AND THE Constitution 16 (Robert A. Goldwin \& Robert A. Licht eds., 1990). See also J Ack N. Rakove, Original MEanings (1996). Rakove discusses the original conceptions of presidential power in Chapter IX, and argues that "[i]n reconstituting the exeeutive, then, Americans paid homage to Montesquieu's principle of separation without allowing his (or Locke's) defense of prerogative to outweigh the lessons of their own history." $I d$. at 250 . While the Framers did change a draft version of Congress" authority to "conduct" war to its authority to "declare" war, this is fully consistent with a conception of Executive authority to conduct war subjeet to congressional regulation. U.S. ConST. art. $1, \S 8$, cl. 11; Rakove, Original Meanings, supra, at 263. 
Thus, whatever might be said on behalf of the Bybee's analysis, a great deal more clearly needs to be said before it could be deemed independently convincing, let alone serve as a foundation stone for an enormously controversial change in the United States' legal conception of its duties to detainees. Yet the memo was influential, serving as the basis for the subsequent and widely disseminated Department of Defense Working Group Report, which set policy for interrogations involving military personnel around the world. ${ }^{50}$ Considering the high professional reputations of the OLC lawyers, the thin legal arguments, and the number of hands the memo passed through, it is hard not to conclude that the Bybee memo was meant more to frame and justify a policy position in ethical and political terms than to provide a legal analysis. Indeed, its legal analysis is now a matter of historical record. After the Bybee memo leaked, and before the confirmation hearings of Alberto Gonzales as Attorney General, the OLC withdrew the memo as an authoritative legal statement and repudiated its arguments as to the scope of "torture." 51 The repudiating memorandum, under the signature of Acting Assistant Attorney General Daniel Levin, displays far higher standards of legal reasoning. It also replaces the pain threshold for torture, previously defined as pain tantamount to that experienced in organ failure, by a requirement of pain or suffering that is "severe" in a concededly undefined but still quite serious way. ${ }^{52}$ As a formal matter, at least, this would appear to leave open the question improperly foreclosed by the Bybee memo, whether significant suffering (arising, for instance, from stress positions or water-boarding) could amount to torture. But the Levin memo specifically does not address the Bybee memo's analysis of the micro-necessity criminal defenses, nor does it take up the Bybee memo's claim that legislation may not constrain the President from acting on military necessity during times of war. ${ }^{53}$

50. Working Group Report on Detainee Interrogations in the Global War on Terrorism: Assessment of Legal, Historical, Policy, and Operational Considerations (Apr. 4, 2003), reprinted in THE TORTURE PAPERS, supra note 7, at 241-85. Also available at http://www.gwu.edu/ nsarchiv/NSAEBB/NSAEBB127/03.04.04.pdf.

51. See Memorandum from Daniel Levin, Assistant Attorney Gen., Re: Legal Standards Applicable Under 18 U.S.C. $\S \S 2340-2340 A$, to James B. Comey, Deputy Attorney Gen. (Dec. 30, 2004) [hereinafter Levin memo], available at http:/www.usdoj.gov/olc/dagmemo.pdf.

52. Id. at 11-I2. The Levin memo also repudiates another of the more peculiar features of the Bybee memo: its oblique suggestion that only a "precise objective" of inflicting severe pain amounts to torture (rather than a purpose of eliciting information, knowing that pain will be used to produce the result). Id. at 16-17; Bybee memo, supra note 7, at 4-5.

53. The legal justification for the administration's controversial program of warrantless domestic surveillance by the National Security Agency appears to rest, in part, on the same claim of legislatively untrammeled Executive authority in national security matters. See Department of Justice White Paper, Legal Authorities Supporting the Activities of the National Security Agency Described by the President (Jan. 19, 2006) [hereinafter White Paper], available at http://permanent.access.gpo.gov/lps66493/ White\%20Paper\%200n\%20NSA\%20Legal\%20Authorities.pdf 
The Levin memo's basis for declining to address the claims of Executive authority was itself peculiar: the President's "unequivocal directive" that U.S. military personnel not engage in torture or other forms of inhumane treatment. ${ }^{54}$ ln other words, the broad limits on Executive power insisted upon by the Bybee memo need not be addressed because of an exercise of Executive discretion: Between the issuance of the Bybee menu and the superseding Levin memo, the OLC apparently took action to ensure that U.S. interrogation policy did not henceforth rely on the controversial Executive power analysis (with the possible implication that the analysis had been relied on to justify practices in the interim) ${ }^{55}$ But the reasoning behind the memo has still not been repudiated, at least to the knowledge of anyone outside the government. To the contrary, the Bybee memo's broad assertions of Executive power have reappeared publicly in two forms: (1) in the "White Paper" analysis provided by the Justice Department in support of its claim that the President acted with inherent constitutional authority in authorizing the National Security Agency to engage in warrantless wiretapping of suspected al Qaeda interlocutors, in apparent violation of the Foreign Intelligence Surveillance Act; ${ }^{56}$ and (2) in the "signing statement" issued by President Bush, when he signed into law the Detainee Treatment Act of 2005, which on its face prohibited U.S. personnel from engaging in "cruel, inhuman, or degrading practices" (CID practices with any detainees). ${ }^{57}$ The signing statement, which followed an unsuccessful administration attempt to lobby against the prohibition of CID practices,$^{58}$ declared:

The executive branch shall construe Title $\mathrm{X}$ in Division A of the Act, relating to detainees, in a manner consistent with the constitutional authority of the President to supervise the unitary executive branch and as Commander in Chief and consistent with the constitutional limitations on the judicial power, which will assist in achieving the shared objective of the Congress and the

54. Levin memo, supra note 51, at 2.

55. See Letter from Daniel Levin to William Haynes, 11, Gen. Counsel at the Dep't of Defense (Feb. 4, 2005), available at http://balkin.blogspot.com/Levin. Haynes.205.pdf. The Levin letter refers to an OLC decision announced in December 2003 by the OLC to withdraw a still-unreleased memo by John Yoo of March 14, 2003, which apparently incorporated the Executive power arguments of the Bybee memo. For discussion, see Lederman's commentary, http://balkin.blogspot.com/2005/07/graham-hearing-on-detainees-progress.html.

56. White Paper, supra note 53, at 6-11. The White Paper also argues that the wiretapping was implicitly statutorily authorized by the Authorization to use Military Force (AUMF), and that it is also permitted by FISA.

57. Detainee Treatment Act of 2005, Pub. L. No. 109-148, Title X, § 1003(a) (2005).

58. See, e.g., Dana Priest and Robin Wright, Cheney Fights for Detainee Policy, WASH. Post, Nov. 7, 2005, at A1 ("Cheney's camp ... believes the president needs nearly unfettered power to deal with terrorists to protect Americans."). 
President, evidenced in Title $X$, of protecting the American people from further terrorist attacks. ${ }^{59}$

In short, the Bush administration has made two distinct propositions about the justifiability of torture and has supported those propositions with its actions even as it has backed away from its legal claims. Those propositions are:

(i) Micro-necessity: a governmental actor may use torture in interrogation at least when torture is the only available and a highly likely means of avoiding a near certain threat of harm graver than that incurred by the act of torture.

(ii) Macro-necessity: the President, pursuing national security or other military objectives, may authorize torture as a necessary response to a threat to national security, irrespective of statutory restrictions.

I turn now to considering these propositions as matters of ethical and political theory.

\section{II}

\section{NeCESSITY, THRESHOLDS AND TICKING BOMBS}

As I remarked at the beginning of this Essay, the core philosophical notion of a right is that rights provide us with reasons to act (or not act), even when considerations about overall welfare raise morally powerful concerns about the consequences of those acts. ${ }^{60}$ There are always illegitimate reasons not to honor a rights claim - my selfish desires give me

59. Presidential Statement on Signing the Department of Defense, Emergency Supplemental Appropriations to Address Hurricanes in the Gulf of Mexico, and Pandemic Influenza Act, 2006 (Dec. 30, 2005), available at http://www.presidency.ucsb.edu/ws/index.php?pid=65259.

60. This is, 1 think, a consensus view of what a deontological conception of rights, or of duties grounding rights, is committed to: a claim of right (or duty not to act in some way) overrides whatever instrumental (welfare-based or other) considerations militate in favor of acting contrary to the right. For its sources in the philosophical literature, see, obviously, IMMANUEL KANT, GROUNDWORK OF THE METAPHYSics of MoRALS Bk. 11 (1785) (our duties as rational agents to treat others as free and equal agents create in them rights not to be used for our purposes, and to be aided in the pursuit of their ends); Robert Nozick, ANarchy, State \& Utopia 30-34 (1977) (the function of rights is to limit, as "side constraints," the pursuit of individual or collective welfare gains); Thomas Nagel, War and Massacre, reprinted in MoRTal Questions 53-74 (1979) (duties to others are deontological constraints which limit the force of consequentialist justifications); SAmuel Scheffler, The ReJection of CONSEQUENTIALISM 80-83 (rev, ed. 1994) (duties not to act in certain ways limit the foree of consequentialist claims).

Ronald Dworkin's famous metaphor of "rights as trumps," suggests a concept of rights as claims that categorically defeat considerations of general policy. However, Dworkin's particular deployment of the concept of a right relies on a quasi-utilitarian theory, according to which rights claims are justified when determinations of general welfare would be corrupted by what Dworkin styles "nosy" or "external" preferences. Such preferences are ruled out by an underlying individual right to treatment (by the statc at any rate) as an equal, entitled to respect. See Ronald Dworkin, Taking Rights SERIOUSLY (1977); for discussion, see Jeremy Waldron, Pildes on Dworkin's Theory of Rights, $29 \mathrm{~J}$. LEGAL STUD. 301 (2000). 
(illegitimate) reason to take your property or to make you an instrument of my desire. Rights claims do rule out such obviously inappropriate claims, but were their force maintained only in such cases, they would have no distinctive content. Long-run welfare-based considerations ("consequentialist" considerations, in philosophers' jargon) about the general misery of a world lived amid theft and abuse would rule those claims out of bounds as well. For claims of right to have distinctive content, for it to be more than a rule of thumb for maximizing welfare, it must apply even in the face of putatively good reasons, particularly if violating the rule would maximize social welfare.

This is a point about the philosophical concept of right, for that concept to have distinctive content. It is not a general justification of rights-a project far beyond the scope of this Essay-nor even a specification of what rights we humans may be said to have. It is simply a point about what the concept must mean, given the role it is meant to play in arguments about morals, politics, and law. But this descriptive, conceptual point has a consequence: it makes clear why a general ethical defense of micro-necessity and a deontological conception of right are incompatible. The necessity justification proposes precisely what the rights claim denies: that action may be taken when the good pays for the bad, as measured by the "cost" of the rights violation. An unconstrained micronecessity justification consists, effectively, in the forcible conversion of a deontological ethical framework into utilitarian one. Necessity justifications ignore the concept of right.

\section{A. The Necessity Defense in Criminal Law: Beyond the Bybee Memo}

Criminal law protects individual rights of bodily integrity and security of possession as much as it protects aggregate social interests such as the maintenance of public order or the rendering of just deserts. Given the disparate goals of criminal law, you might think that theoretical discussions of the necessity defense would recognize the inherent limits of any basically utilitarian mode of argument applied to individual rights. On the contrary, Anglo-American criminal law theorists and treatise writers, including the authors of the MPC, are typically critical of the courts for giving the necessity defense so little force beyond its formal recognition. Theorists complain about the failure of common-law courts to extend the justification beyond its well-recognized instances (where it typically justifies regulatory violations, such as speeding en route to the hospital or very local property violations). ${ }^{61}$ And on "economic" theories of criminal

61. On the potential justifiability of killing a non-threatening individual, see LAFAvE, supra note $30, \S 10.1(a)$; MPC Commentaries, supra note 23, 33.02 , Commentary 3; Glanville Williams, Criminal Law: The General Part $\$ 237$ (2d ed. 1961); Sanford H. Kadish, Blame and Punishment 122-23 (1987). George Fletcher is a rare criminal law theorist who explicitly rejects a 
law, where the point of the criminal norm is to block transactions that could, were they Pareto-improving, go through with mutual consent, the necessity defense would, indeed, exemplify the logic of the criminal law in general - a form of "efficient breach" theory. ${ }^{62}$

To some extent, legal theorists' quick assumption that necessity can be assimilated into the criminal law generally reflects the contingent fact that many of these writers have, independently, utilitarian sympathies. But the lack of attention to the evident incompatibility of right and necessity reflects more than ideological blinders. There are several additional factors at work. To begin with, the basic comparative-value conditions of the necessity defense are virtually never satisfied in practice. Criminal conduct is paradigmatically conduct that causes far more harm to the victim and society than it gains the perpetrator, whether or not the criminal norms are themselves justified in deontological or consequentialist terms. Were society rife with wanton Benthamites rather than egoists, the question of necessity's scope would be ever-present. As it is not, the illusion of consonance is more easily maintained.

The relatively few decisions on the necessity defense meet this pattern: necessity claims usually lose, and when they win, it is for easy cases, which fall far short of the infliction of violence, let alone homicide (excluding self-defense). This statement from a recent California case, People v. Coffman, is typical: "It is not acceptable for a defendant to decide that it is necessary to kill an innocent person in order that he [or she] may live." 63 To the extent that there is any Anglo-American authority for granting the defense in cases of homicide, it is typically in cases (or, more often, hypotheticals) involving a choice between certainly killing some and probably letting all die, as with shooting down a possibly hijacked jet plane, or pulling a fear-frozen shipwreck victim from a ladder so that others might pass, or throwing some passengers into the sea lest all drown in the overcrowded lifeboats. ${ }^{64}$ Commentators have sought to extend this

much less restrictive necessity test. See George Fletcher, Rethinking Criminal Law $\S 10.4$ (1978). J.C. Smith notes that if English law does permit application of the defense to cases of homicide (unclear, given the infamous $R$. v. Dudley \& Stephens precedent, 14 Q.B.D. 273 (1884)) the defense does not extend past cases of killing some lest all die. Sir John Smith \& Brian Hogan, Criminal LAw 271-74 (10th ed. 2003).

62. See Richard A. Posner, An Economic Theory of the Criminal Law, 85 Colum. L. REv. 1193, 1193-1231 (1985).

63. 34 Cal. 4th 1, 100 (2004), cert. denied, 544 U.S. 1063 (2005) (denying necessity defense in robbery-murder where defendant alleged co-perpetrator had threatened her life and the life of her son) (internal quotation marks omitted).

64. SMith \& Hogan, supra note 61, at 272-73; United States v. Holmes, 26 F. Cas. 360, 1 Wall Jr. 1 (C.C.E.D. Pa. 1842). By contrast, the defense was famously denied in Dudley \& Stephens, in part on the ground that there was no reason why the cabinboy, rather than any of the others, should have been killed for food, as well as on the ground diseussed before, that the court (though not the trial jury) thought they had not waited long enough for rescue before turning to cannibalism. For more discussion of this peculiar case, see A.W. Brian Simpson, CANNibalism and The Common LAW (1984). 
line of cases into true trade-offs, such as the MPC hypothetical in which an inhabited family farm is deliberately flooded in order to save a town. ${ }^{65}$ But this highly revisionary aspect of the MPC defense has not been incorporated into law, and the fact remains that there are no decisions in Anglo-American law, nor any documented decisions not to prosecute, in which innocents not otherwise in harm's way are assaulted or killed in order to avert harm from others.

The same appears also to be true in European jurisdictions. France's Penal Code exculpates a defendant who, "facing an immediate or imminent danger to himself, another, or his property, performs an act necessary to save the person or property, provided the means used are proportionate to the seriousness of the threat." ${ }^{66}$ In principle, the defense covers all crimes, including assault or homicide, but I have found no recorded decisions showing even rejection of the defense in such cases. ${ }^{67}$ Germany's Penal Code has a virtually identical provision, called the "state of emergency" (Notwehr) defense, but it adds a requirement that the means be "appropriate" to the harm averted. This is read by some commentators, including criminal law theorist George Fletcher, categorically to exclude at least homicide from the scope of the defense. ${ }^{68}$ Again, I have found no cases justifying the assault or killing of an innocent not already in harm's way. Fletcher cites one case rejecting the defense, in which a German officer was found guilty of battery for beating Soviet prisoners in order to interrogate them regarding whether they had been stealing food and thereby, the officer maintained, threatening the well-being of all. ${ }^{69}$ The standard Continental examples of successful necessity defenses are, in essence, gleaning cases: squatters found justified in taking over abandoned

65. MPC Commentaries, supra note $23, \S 3.02$, Commentary 3

66. C. PÉN. art. 122-7 (translation by author). In principle, the defense covers all crimes, including assault or homicide, but 1 have found no recorded decisions showing even rejection of the defense in such cases.

67. Jacques-Henri Robert writes that "although one can defend using forcc against someone posing a threat to the household [patrimoine] . . . necessity will not lie against an innocent." DroIT PÉNAL GÉNÉRAL 272 (Paris: Presses Universitaires de France, 5th ed. 2001) (translation by author). The defensible cases of necessity hc instances are of the familiar Anglo-American variety: sailors jettisoning some of their number lest all die, and surgeons cutting flesh without consent in order to save life.

68. Deutsches Strafgesetz $\S \S 32-34$. German and French criminal law, unlike Anglo-American law, do in principle permit the excusc of duress for killing of the innocent, as does the I.C.C. Statute, $\S$ $31(1)(d)$, although the homicide limitation had been recognized before, e.g., in Prosecutor v. Erdemovic, ICTY (Appeals Chamber), IT-26-92, judgment of 7 October 1997. For discussion, see Gerhard Werle, Principles of International Criminal Law 146 (The Hague: T.M.C. Asscr Press, 2005). In German law, intcrrogatory torture is subject to multiple specific prohibitions, apart from any inherent limitations in the necessity defensc. Notwithstanding the prohibitions, in a recent article Winfried Brugger performs interesting interpretive acrobatics to show how torture might be justified under German law. May Government Ever Use Torture? Two Responses from German Law, 48 Ам. J. СомP. L. 661 (2000).

69. FleTCHER, supra note 61 , at 784 . 
housing, breaking and entering to shelter poor children, and in principle the theft of food (though it is generally impossible to show that theft was the only option). ${ }^{70}$

\section{B. Necessity in Moral Philosophy}

This leads to the two positive, deeper, reasons why legal commentators and moral philosophers continue to discuss micro-necessity as though it were easily compatible with systems of rights. First is the deontologist's embarrassment at the stance's apparent absolutism, its rejection of any concessions to catastrophic considerations in the name of right. Fiat justitia, pereat mundus - Let there be justice, though the world may perish - ought to be disproof of a moral theory, not its motto. How can one both accept principled exclusion of the gains to be made through the commission of wrongs in some cases, while insisting that the gains be foregone even if that means the end of the morally upright existence? While belief in an afterlife would do the trick, that is not an available option for a secular ethic. ${ }^{71}$

The problem is real, but solutions have not been apparent. To reckon with the embarrassment, rights enthusiasts therefore declare themselves deontologists up to a "threshold" of "disaster," after which point welfare considerations are taken to dominate rights claims. ${ }^{22}$ For example, Michael Moore uses the metaphor of a dam to explain the finite scope of deontological restrictions: welfare-based considerations build up on one side of the deontological dam until finally they spill over, justifying whatever polices were foreclosed by the "dam" of principle. ${ }^{73}$ But, according to Moore, the dam remains and re-emerges once the welfarist waters recede.

The image of a threshold, a dam, or some other discontinuously permeable barrier of principle is tempting, for it captures the form of popular intuitions that (a) it must be wrong, and not merely a poor choice in cost-benefit terms, to inflict some serious evil in exchange for a local benefit; while (b) it seems like an indulgent and even insane insistence on one's own moral purity to insist on principle in the face of really catastrophic costs. In the famous line of moral philosopher William

70. Id. at $§ 10.2$; ROBERT, supra note 67 , at 272.

71. Rewards in the afterlife are, in fact, Plato's apparent solution to the conundrum of the good man faced by evil circumstance, in the "myth of Er," in Book X of the Republic.

72. Leading claimants of the threshold theory are, e.g., Thomas Nagel, War and Massacre, supra note 60; Nagel, Personal Rights and Public Space, 24 PhlL. \& Pub. Aff. 83 (1995); Robert Nozick, Anarchy, State, and Utopia 41 (1975); Charles Fried, Right and Wrong (1978). But some version of the position is nearly universal among non-instrumental rights theorists.

73. Moore, supra note 26, at 332. For discussion, see Lamy Alexander, Deontology at the Threshold, 37 SAN DiEgo L. Rev. 893 (2000). 
Frankena, "Morality is made for man, not man for morality."74 The trouble is that although the threshold image is apt, it merely describes rather than explains how deontological principles could function in this way. To be unbearably literal, principles have no underlying physical anchor, as does a literal dam; to be slightly less literal, nor do they have a determinate and finite jurisdiction, like the laws of a polity. They are, rather and simply, expressions of value: that some acts are wrong, or that others are permitted, or that they are required..$^{75}$ One might defend complex principles that state, for example, that an act is forbidden unless a certain condition is met. But given what is supposed to be (and appears intuitively as) a primitive, basic concept of being forbidden, period, such principles look simply incoherent. More to the point, such principles raise the classic problem of establishing the marginal trade-off once the values are no longer absolute. Put crudely, once principles have a price, all that is left is the bargaining. This is, of course, the intellectual force of the ticking-bomb hypothetieal, which I turn to below. Threshold deontology doesn't avoid this embarrassment, but merely pretends it does not exist.

The apparent incoherence of threshold deontology explains why the most prominent foundational account of deontological ethics (Kant's) is commonly criticized for its absolutism. The underlying value of rational dignity is, in Kant's literal term, priceless - incomparable against any other range of goods. ${ }^{76}$ The pricelessness of principle is, in fact, its deepest feature and gives rise to the deepest and most notorious puzzle about deontological conceptions: the so-called paradox of rights. This paradox inheres in the fact that rights claims bar consideration of consequences even when these consequences include identical (and larger-scale) rights violations. Thus, one person's right not to be killed (or murdered) will not be outweighed by the benefit of saving two, or more, others from being killed (or murdered). How can the considerations that support honoring the right on one side of the relation not simultaneously demand honoring it on the other side? Again, philosophers have mainly described rather than argued for stances and commitments consistent with tolerating the

74. William K. Frankena, Ethics 116 (2d ed. 1973).

75. In Stig Kanger's influential formulation of "deontic logic," or the logic of obligations, all principles can be reduced to statements involving the operator "is required": an act is forbidden if it is required that one not do it; it is permitted if it is not required that one not do it, and not required that one do it. Stig Kanger, New Foundations for Deontic Logic, in New Studies in DeonTic Logic (Risto Hilpinnen ed., 1971).

76. KANT, supra note 60 , at 4:435. Nagel's conception of moral rights as grounded in "status," something that can be neither redistributed nor increased in quantity, is similarly absoute in form, though he says (without defending the claim) that assertions of right are consistent with thresholds. Nagel, Personal Rights supra note 72, at 85, 88 (1995); F.M. Kamm, Non-consequentialism, the Person as an End-in-Itself, and the Significance of Status, 21 PHIL. \& PUB. AfF, 354, 381-89 (1992). Both are interpretations of Kant's claim in the Groundwork that the value of rational agency can only be captured by the concept of "dignity" rather than "price." Groundwork 4:434. For still the most acute discussion of the paradox, which insists on its puzzling character, see SCHEFFLER, supra note 60. 
paradox: that the value of the person protected by the right is not aggregable across persons, but instead simply demands respect, or that the reasons supporting rights claims are in the form of principled demands, not invitations to maximize. ${ }^{77}$

These formulations are appealing, but they are not justifications. Each might be seen as expressing a conception of individuals as free and equal beings, with lives of individual and distinct value. This was Kant's view, and whether or not one accepts his argument for it on the basis of rational necessity, it remains a deeply entrenched and fundamentally attractive feature of modern political and ethical thought. Nozick has put the point poignantly: "[Using] a person [for another's gain] does not sufficiently respect and take account of the fact that he is a separate person, that his is the only life he has." 78 But the paradox remains, especially in the face of catastrophe, when the actor is faced with a choice between honoring the value in one instance and countenancing its destruction many times over.

Let us look now at the infamous ticking bomb, which can seem to present that puzzle in a particularly troubling way. In the standard story, an interrogator is faced with a terrorist who has planted a bomb that will kill many innocent citizens. Torturing the terrorist is the last, best hope for saving them. The first thing to be said, and the first thing that was said, in Henry Shue's seminal article twenty-five years ago, is that at best the ticking-bomb hypothetical is of virtually no practical significance, and at worst it is utterly corrupt in the illicit conclusions it invites. ${ }^{79}$ The example gains its force from its stipulated perfect satisfaction of all the traditional criteria of necessity: the interrogator is certain of the threat and its attendant costs, knows that the person to be tortured is responsible for the bomb, and is reasonably certain that torturing him is the sole means of avoiding catastrophe and is likely to be effective. While under these conditions, there might be widespread consensus that torture would be justifiable, relax any of the dimensions of justification-maybe it's a hoax, maybe it's the wrong guy, maybe the interrogator has chosen to torture the terrorist's child instead, maybe the suspect will lie-and dissensus emerges immediately.

In the real world, it is most likely that some or all of the traditional criteria will be unsatisfied. Moreover, institutions and institutional actors tend to abuse the limits of their discretion and coerced confessions are

77. T.M. Scanlon, What We OWe to Each OTher 83-85 (2000). More precisely, Scanlon says that the reason not to violate an agent-centered restriction could be grounded on a principle whose justification itself lies on the contractarian footing that no one searching for principles to provide a fair basis for regulating common life could reasonably reject; this is not, in his view, a "teleological" (or maximizing) conception of value.

78. Nozick, supra note 60 , at 33.

79. Henry Shue, Torture, 7 PHIL. \& PuB. AfF. 124, $142-43$ (1978). 
demonstrably of inferior intelligence quality to detective work. ${ }^{80}$ For all these reasons, attempts to institutionalize any principle of morally permissible torture invariably either(1) define the circumstances under which torture is permissible so narrowly that the requisite criteria are virtually never met; or (2) define the circumstances under which torture is permissible so broadly that the torture is allowed even when it is not morally justified. ${ }^{81}$ To the extent that the Bybee memo goes beyond the hypothetical exploration of an ex post defense to a charge of torture and actually lays out ex ante an institutional space for torture (grounded in the qualified immunity of officials relying on its legal advice), 1 believe it is tantamount to criminal complicity. ${ }^{82}$

With all these considerations against it, the persistence of the tickingbomb hypothetical might seem hard to explain. Since the conditions under which its conclusion results never actually obtain, it might be best to treat it as a kind of ethical "singularity," a black hole that swallows up intuition and lets nothing emerge. But, in fact, the ticking-bomb example is no harmless anomaly. lt persists because of a series of related mistakes in thinking about rights under pressure from welfare, and how to conceive the role of necessity in these cases. Necessity really does justify overriding some kinds of rights claims in many instances, but these are rights of a fundamentally different nature from the ones involved in the ticking-bomb example. Criminal theorists have over-generalized the appropriate normative scope of the necessity defense by confusing those rights whose abrogation the defense can legitimately justify with all rights.

\section{Institutional versus Pre-Institutional Rights}

Let us put aside, for a moment, the cases of torture and ticking bombs and shift to the law of torts and property. As controversial. as a legal decision authorizing homicide or torture would be, so uncontroversial are decisions in tort cases like Vincent v. Lake Erie Transp. Co., or Ploof $v$.

80. John Langbein quotes Sir James FitzJames Stephen's A History of the Criminal Law of England, concerning "the proclivity of the native police [in India] for torturing suspects. 'It is far pleasanter to sit comfortably in the shade rubbing red pepper in some poor devil's eyes than to go about in the sun hunting up evidence." John H. Langbein, The Legal History of Torture, in TORTURE: A Collection 93, 101 (Sanford Levinson ed., 2004). Notably, Justice Frankfurter also quotes Stephen in $M c N a b b$ v. United States, 318 U.S. 332, 343 (1943), an important coerced-confession case in which the Court asserted its inherent authority to regulate federal investigatory authority.

81. There is no way to institutionalize any principle of permissible torture without falling into the swamp of Abu Ghraibs and Bagrams, in which innocents are routinely subjected to abuse for the amusement of sadists playing "intelligence" games. On the abuses at Bagram, see Tim Golden's exposé, In U.S. Report, Brutal Details Of 2 Afghan Inmates' Deaths, N.Y. TımEs, May 20, 2005, at A1.

82. 1 defend these claims in The Lawyers Know Sin, supra note 19, at 241. Briefly, there exists a basis for accomplice liability for any purposefully abetted acts of assault or torture, and for purposefully abetting acts, in reckless disregard of the risks, that through recklessness or negligence led to the deaths of some of the detainees. 
Putnam, ${ }^{83}$ which involved intentional trespasses upon property clearly justified as necessary under the choices of evils at hand. So clear is the force of the necessity defense in such cases that no prosecutor would consider them, and the question of justice is simply who should pay the costs. As I discussed above, criminal necessity defenses are generally found to lie in affronts to property rights, as well as to violations of regulations that impair no rights. ${ }^{84}$ The difference might be thought simply a matter of the relatively weaker interests at play, property versus life, but I think it goes deeper than that, to the kind of right the law of property protects, versus the kind of right protected by homicide law-or, in the instant case, by $\S 2340$ and the body of international treaty and customary law that stands behind it. ${ }^{85}$ This is the difference between what I want to call institutional and pre-institutional rights. ${ }^{86}$

Institutional rights are the rights consequentialists defend: individual claims secured by a general promise that their respect will promote welfare. Pre-institutional rights, by contrast, are claims that institutions must honor, and the institutions' basic justice or legitimacy is assessed by reference to these claims. At least since David Hume, property rights have been broadly (if not universally) understood to be of the institutional sort, both philosophically and positively. They constitute a conventional system of assigning ownership whose specific forms are grounded instrumentally, not in claims of natural right. As a matter of positive law, informal social institutions, and economic arrangement, this point is clearly true. There is simply no way to understand our complex system of divided intcrests and

83. 124 N.W. 221, 222 (Minn. 1910) (holding boat operator acted justifiably, but still liable for damage to dock incurred during unconsented use during storm); $81 \mathrm{Vt}$. 471, 474-75 (1908) (plaintiff had right to compensated use of defendant's dock during storm).

84. Arguably, this is not quite right. If one accepts a right to be free from eertain degrees of ex ante risk, then a speeding driver on the way to the hospital may be violating the rights of those he endangers. French criminal law explicitly treats the issue in this way, and deems it a matter of justified necessity. RoBERT, supra note 67, at 273-77 (citing CA Metz, 8 mars 1990, Dr. pén., 1991, comm. 49).

85. Apart from the Convention against Torture, torture is categorically prohibited by the International Covenant on Civil and Political Rights, 999 U.N.T.S. 171 (Dec. 16, 1966); by all four Geneva Conventions, through both Common Article 3 and through specific articles: Geneva Convention for the Amelioration of the Condition of the Wounded and Sick in Armed Forces in the Field, 75 U.N.T.S. 31; Geneva Convention for the Amelioration of the Condition of Wounded, Siek and Shipwrecked Members of Armed Forces at Sea, 75 U.N.T.S. 85; Geneva Convention Relative to the Treatment of Prisoners of War, 75 U.N.T.S. 135 [hereinafter GC IIl]; Geneva Convention Relative to the Proteetion of Civilian Persons in Time of War, 75 U.N.T.S. 287 [hereinafter GC IV]. All were signed 12 Aug. 1949. The rule against torture is also seen as a non-derogable, jus cogens norm of eustomary international law. See, e.g., ReSt. (Third) of Foreign Relations LaW of the United STATES, $\S 702$, and Reporter's Note 5 .

86. 1 borrow the idea of the institutional vs. pre-institutional distinction from John Rawls, though he uses it to discuss the related issue of desert. JoHN RawLs, ThEORY OF JUSTICE $\S 48$ (2d ed. 1999). 
fractionated claims, much less to justify the economic systems that depend upon them, except on an instrumental, conventionalist basis. ${ }^{87}$

Within contemporary philosophical thought, to the extent that views of property rights as natural have any lingering force, it is largely to defend claims that the capacity to own property must be conceived preinstitutionally, or that individuals must have some minimum of personal property in order to be recognizable as equal subjects under law. ${ }^{88}$ Even if one accepts the most prominent version of a stronger, Lockean theory of pre-institutional property rights, that of Robert Nozick, this theory does nothing to vindicate current patterns of holdings, or the legal doctrines that prevent disturbances to those patterns. Current patterns of holdings, on any realistic view, are built on histories of force and fraud, and cannot be consistent with any understanding of what pre-institutional rights to acquisition and transfer would demand. As an account of the way in which property is normatively conceived today, we are deeply committed to both conventionalism and instrumentalism. ${ }^{89}$

Now, the problem with instrumentalist conceptions of rights is that they only work well in the easy cases, when honoring them also promotes welfare. For this reason, they might best be regarded as pseudo-rights. Given some natural assumptions about the value of stable institutional expectations, many cases will turn out to be easy, and markets transferring those rights can function efficiently. But sometimes the instrumental calculus points the other way, even taking into account indefinite future costs and benefits. And when defenders of an instrumentally justified right are faced with the clear choice-respect the right or promote welfare-they must opt for welfare, on pain of being accused of deontological "ruleworship." ${ }^{90}$ The consequence is that instrumentally justified rights must go hand in hand with an unrestricted limit of necessity: the right will be

87. See Elizabeth Anderson's reflections that Lockean property rights would be ineompatible with the conditions of modern capitalism: "How Not to Complain About Taxes (II)," http://left2right.typepad.com/main/2005/0I/why_i_reject_na.html. In the U.S., of course, intellectual property is instrumental and conventional as a matter of constitutional text: "To promote the Progress of Science and useful Arts, by securing for limited Times to Authors and Inventors the exclusive Right to their respective Writings and Discoveries." U.S. CoNST. art. $1, \S 8, \mathrm{cl} .8$.

88. These are, roughly, the "personality theory" views of Kant and Hegel, well discussed by Jeremy Waldron, The Right to Private Property (1990); Margaret Jane Radin is a modern inheritor of these views - see CONTESTED COMMODITIES (I991).

89. In these paragraphs I have oversimplified grotesquely. 1 discuss the failings of preinstitutional property theories at greater length in Justice in Reparations: The Cost of Memory and the Value of Talk, 32 PHIL. \& PuB. Aff. 277, 277-312 (2004).

90. These are familiar points, found most easily in J.J.C. Smart's An Outline for a System of Utilitarian Ethics, in J.J.C. SMarT \& Bernard Williams, UTILITARIANism: For and Against (1973). Contrary to Smart, I do not want to claim that rule-utilitarianism "collapses into"-is extensionally equivalent to-act-utilitarianism. As Donald Regan has shown, rule-based forms of utilitarianism can promote utility in a way that individualistic act-utilitarianism cannot, by solving coordination problems. Utilitarianism and COOPERATION (1980). But the case at issue here is not coordination dependent. 
respected so long, and only so long, as that respect pays out in the longterm aggregation of welfare.

We know what an explicit version of such a scheme looks like because we live with it everyday. Takings doctrine, according to which property rights are secure so long, and only so long, as the state has not determined that the public would not further benefit from an alternative use of the property. ${ }^{91}$ The recent Kelo ${ }^{92}$ decision perfectly represents the instability of an instrumental approach to property. As Thomas Merrill has observed, what was chiefly remarkable about Kelo was the public furor it evoked, notwithstanding its unremarkableness as a piece of doctrine. ${ }^{93} \mathrm{Kelo}$ simply followed doctrinally in a long line of cases permitting Takings that the state could justify by reference to some aggregative benefit, independent of any formalistic requirement of "public use." Translate "public use" into "public necessity," in Blackstone's phrase, and it is clear that Takings law embodies the concept of micro-necessity. ${ }^{94}$ Whatever substantive criteria of judicial review remain in Takings doctrine can best be seen as forcing the assessments of competing values in the direction of the certainty of a welfare gain. When the contingent, instrumentalist foundations of property rights were suddenly laid bare for all to see in the ensuing media coverage, public uproar was entirely to be expected, at least by those who feared their property might become subject to public use or necessity.

\section{Limits to Necessity in War}

There is another scene where rights become uniformly subject to necessity, and which ought to disrupt more than bourgeois complacency. ${ }^{95}$ This is the scene of civilians caught in war, where rights to life are balanced against aggregative concerns. Under the principles and agreements of international humanitarian law and the law of armed conflict, while civilians or their property may not be directly targeted, they may incidentally be killed or their property destroyed, subject to military

91. Note that while the point of the "just compensation" requirement is to push Takings in the direction of Pareto efficiency, given that actual compensation is frequently less than the owner's subjective value, the actual normative justification is more Kaldor-Hicks than Pareto. A different version of the same principle is at work in the Vincent cases: there will be no criminal liability, assuming Kaldor-Hicks efficiency, and then ex post compensation to bring the transfer to "objective" Pareto standards.

92. Kelo v. New London, 545 U.S. 469, 125 S. Ct. 2655 (2005).

93. Testimony of Thomas A. Merrill to Senate Committee on the Judiciary, Sept. 19, 2005, available at $\mathrm{http}: / / \mathrm{judiciary}$.senate.gov/testimony.cfm?id=1612\&wit_id=4661.

94. What is puzzling is Justice Thomas' dissenting argument that the Framers, by changing what appears to be Blackstone's prohibition on Takings even for "public necessity" into a permission to take for "public use" provided that just compensation is paid, somehow meant to eapture the restrictiveness of Blackstone's own view. $125 \mathrm{~S}$. Ct. at 2677 (Thomas, J., dissenting).

95. I say this as a complacent bourgeois. 
necessity. ${ }^{96}$ Their rights to life and property are to be respected, so far and only so far as that respect is not overly costly to the tactical goals of the military commanders. This form of utilitarianism is more restrictive, insofar as potentially optimal strategies of targeting civilians are categorically ruled out, and insofar as the requirements of "necessity" and "proportionality" are supposed to have more bite than simple weighing of costs versus benefits. But the consequences of this regime for civilians caught in war are enormous. The invading and subsequently occupying U.S. military in lraq is probably as disciplined and effective as any force in history at attempting to keep civilian casualties within the guidelines of international law. The effect is that rights generally honored in nearabsolute terms become subject to a highly institutionalized and conventionalized calculus, whereby target planners route their proposals through military lawyers to ensure conformity with law. Even so, estimates of civilian casualties directly traceable to U.S. (or coalition) actions are in the range of 7000-10,000 dead, with estimates of total civilian deaths in the range of 25,000-30,000. ${ }^{97}$ Still, the rate of civilian deaths in the current conflict is considerably lower than in other wars. Estimates of civilian/combatant casualty ratios for the twentieth century as a whole range from 2:1 to $10: 1$.

My point is not that war is terrible for civilians. It is rather to suggest what a regime of rights limited by necessity looks like. Importantly, the regime of legal rights against torture does not look like this, any more than the right against homicide in domestic law looks like the right to property under the discipline of the Takings clause. That the right against torture is not like this, not subject to instrumental calculation, is-ironicallyperhaps most evident at war, where the torture of even a captured combatant with tactical knowledge is absolutely proscribed. ${ }^{98}$ This point had become so deeply embedded in the law and training of the modern military before the Iraq and Afghanistan invasions and occupations that no

96. See, e.g., GC IV, supra note 85 , art. 147. "Military necessity" is an extraordinarily plastic term. According to one classic statement, "Military necessity permits a belligerent, subject to the laws of war, to apply any amount and kind of force to compel the complete submission of the enemy with the least possible expenditure of time, life, and money." United States v. List, in Trials of WaR Criminals before the Nuremburg Military Tribunals Under Control Council Law No. 10 1253-54 (1949). The regime of military necessity is more like egoism than utilitarianism, albeit constrained by protection of the innocent from deliberate targeting.

97. The figures come from the "Iraq Body Count" project, which is regarded as very credible. It consolidates all reports by news agencies of civilian deaths, and claims to triple-check all of them. The project attributes $37 \%$ of the civilian dcaths directly to U.S. and coalition military action. See http://www.iraqbodycount.net/press/pr12.php.

98. GC III, supra note 85, art. 17(1) (prohibiting coercive interrogation, including torture, of any lawful combatant taken prisoner of war); GC IV, supra note 85 , art. 32 (prohibiting torture of any "protected person"-civilian citizen of a contracting party); Protocol Additional to the Geneva Conventions of 12 August 1949, and Relating to the Protection of Victims of Non-International Armcd Conflicts, art.4 (Protocol II) (Dec. 7, 1978) (prohibiting torture of prisoners taken in civil insurgencies). 
one was angrier about the attempt by the civilian leadership of the Bush administration to relax the rules on interrogation than the professional military, especially its lawyers and officers. In particular, the officers expressed concern over the decision, in Bush's terms, to subordinate detainee rights against inhumane treatment to "military necessity." What disturbed the officers, apart from concerns about reciprocity inflicted upon our own soldiers, was that a right specifically excluded from the instrumental calculus was now included. For the right against torture, along with the other rights whose violation constitutes grave breach of the Geneva framework, ${ }^{100}$ is the background set of principles against which the particular institutions, permissions, and conventions of war are justified. ${ }^{101}$ To put it positively, they are the pre-institutional backdrop against which the institution itself can legitimately be maintained. If there were not restrictions on the killing of civilians or the mistreatment of any persons during the war, the specific set of combat privileges that constitute the Law of Armed Conflict would simply make no sense. If nothing were restricted, then everything would be permitted.

A full account of the force of the right against torture would focus on the peculiar horror of torture, the combination of suffering with the deliberate subordination of the victim's consciousness to the will of the interrogator. ${ }^{102}$ But it would share with the peacetime right against homicide a commitment to the value of the individual life, a value that cannot be aggregated, or so our legal and moral theories have generally presumed. The scene of torture, in the imagination of those who reject it, makes the nature of this value especially clear: the interrogee is not confronted as a part of an armed host, but as an individual, already disarmed and vulnerable. ${ }^{103}$ This is the field of basic, pre-institutional human rights. There is something unfortunate about Dworkin's oft-invoked metaphor of "rights as trumps." The metaphor suggests that rights are

99. Memorandum to the Vice President from President George Bush, Re: Humane Treatment of al Qaeda and Taliban Detainees (Feb. 7, 2002), reprinted in THE TORTURE PAPERs, supra note 7, at 135 (directing U.S. Armed Forces "to treat detainees humanely and, to the extent appropriate and consistent with military necessity, in a manner consistent with the principles of Geneva," even though, as a matter of law, the Geneva Conventions do not apply).

100. These are rights against murder, cruel or degrading treatment or other "outrages upon personal dignity," being taken hostage, or summary execution. Common Art. 3(1)(b). While POW rights to facilities for "sports and games" (GC 111, Art. 39) might be an instance, it is hard to imagine what else now-Attomey General Gonzales had in mind by labeling as "quaint" the provisions of the Convention.

101. I take up some of these points in The Difference Uniforms Make: Collective Violence in Criminal Law and the Law of War, 33 PHIL. \& PUB. AFF. 148 (2005).

102. For excellent discussions, see Luban, supra note 2; David Sussman, What's Wrong With Torture?, 33 PHIL. \& PUB. AFF. 1 (2005).

103. Of course, from the perspective of the interrogators, it is this seene that renders the victim least human, as Hannah Arendt observed of the eoncentration camp inmates. HANNAH ARENDT, ThE ORIGINS OF TOTALITARIANISM, 284 (1973). 
moves in a game, and that the game is separable from the players. This might be an appropriate picture of rights in a court of law introduced as part of a debate about what ought to be done. But there is no argument in the torture chamber; there is merely one person preparing to do violence to another. In such a context, rights are simply constraints on how one person may treat another. They may not be observed, but they exist as moral claims whether or not the justificatory game is played.

\section{E. Summary}

In criminal law, the defense of necessity runs out when it confronts pre-institutional rights, whose value is not the product of an instrumental calculus. ${ }^{104}$ My point is not that we could not conceive it in these terms, nor even that we do not, since obviously some people do. My point is that the tradition of criminal law, across the civilian and Anglo-American spectrum, is remarkably fallow ground for justifying acts of violence against individuals, outside either the peculiar space of warfare, or the narrow context of immediate self-defense. While torture and other forms of intentional violence against persons occur on the battlefield as well as in the station house, such acts have received no official legal authorization beyond the awkward discussion in the Israeli Supreme Court and the Bybee memo in the United States. Criminal law theorists have commonly remarked that the near-absolute value of life shows that the law "reflects a moral uneasiness with reliance on a utilitarian calculus." 105 It would be more precise to say that the law responds in a utilitarian fashion to institutional rights and in a non-utilitarian fashion to pre-institutional rights.

III

\section{Necessities at War: FaCt versus Justification}

I have so far argued that we operate across ethics, politics, and law with two distinct concepts of rights. Institutional, instrumentally justified rights - of which property rights are exemplary - are subject to override by what I have called a micro-necessity justification. But pre-institutional rights, which reflect a conception of the distinct value of individuals, are as a conceptual matter immune to micro-necessity overrides. Assertion of a necessity justification in their face simply denies their deontological status. Rights against torture are core examples of pre-institutional rights and so it

104. I want to put aside the very different case of knowingly running ex ante risks of statistical deaths, even risks up to a moral certainty. Such risks can, I think, be justified on a basis consistent with individual rights. I discuss this briefly in Self-Defense and Political Justification, 88 CaLIF. L. Rev. $751,751-58$ (2000).

105. See, e.g., KaDisH, supra note 6I, at 123. 
follows logically that they are immune from violation justified by necessity.

But, while recognizing this distinction helps to make clear why necessity justifications have the limits they do, this does nothing to solve the puzzle posed by the ticking-bomb case, or more generally by the paradox of rights. Pernicious as the example is, it still demands a rational account, for it puts great pressure on the essential element of deontological reasoning, namely, its categorical, exceptionless character. If justified departure is not the response, what is?

At this point, it is worth paying even closer attention to the way the standard necessity justification is not really about necessity, but about the conditions under which actors may exercise judgment to depart from conventionally secured rules. As I explained above, real, existential necessity does not play a role in the necessity defense: in the real world, there can never be absolute certainty that the threatened harms will materialize, or that there are no other options, or that the strategy in question will be effective. Functionally, the necessity justification is an ex post application of an ex ante (and unconfirmable) probabilistic weighing of various courses of action. But in the hypothetical, idealized case, the ticking-bomb example does confront us with real necessity, if only in our imaginations. Confronted by real, existential necessity, we find that our principles yield. But we must be precise about what this means. The image of ourselves torturing, or authorizing torture, is not a deduction from ethical principles. It is rather a recognition that our principles could imaginably be unable to withstand the pressure from concrete, opposing values.

It may seem peculiar, even unintelligible, to claim that we can respond to necessity in a way that neither excuses (for we are responsible for our choices) nor justifies. Nonetheless, it is a familiar stance, one whose invisibility is itself a product of its familiarity. Bernard Williams' magnificent account of ancient Greek ethical thought, Shame and Necessity, provides a possible model in its discussion of slavery. Chattel slavery was an ordinary and deeply rooted part of ancient Greek life, and the economies of the city-states pervasively depended upon it. It was a kind of chance that made people-mostly non-Greek-speaking peoples, to be sure-into slaves: the chance of being captured at war, or by slave-hunters. What is essential to Williams' account is that this chance-like feature of slavery was widely recognized by Greeks. They saw it, he says, as "arbitrary and cruel," as "a paradigm of disaster, of which any rational person would complain." All the same, it was a part of their world, and they lacked the imagination, or the will, to put anything else in its place. As a consequence, Williams says, they saw the slavery system as "not just but 
necessary." They treated slavery as necessary in fact but derived no lesson of justification from this necessity. ${ }^{106}$

Aristotle, however, departed from this stance. He did not merely accept slavery, but actively defended it. In the Politics, he set himself to the task of showing why the slave system was not only necessary but also just. ${ }^{107}$ Prefiguring later racist ideology, Aristotle argued that slaves were essentially animals rather than humans, suited by nature to be coerced by their masters, who in turn were suited by nature to rule. ${ }^{108}$ Regarding this step from necessity in fact to justification, Williams remarks, "if there is something worse than accepting slavery, it consists in defending it." 109

Why should this be so? Why not think that the attempt to offer a justification for a disputed practice at least credits the power of reason, as mute acceptance does not- the tribute vice pays to virtue, in the words of La Rochefoucauld? In cases of genuine normative dispute, the practice of seeking justification in terms of broader principles is part of the underlying practice of ethics itself. But when the acts or institutions to be justified present, on their face, such a disruption to ordinary principles of ethicaI thought-in slavery's case, concerning the lives people hope to lead-the practice of justification looks more like rationalization than genuinely ethical deliberation.

Let me be precise about the point of invoking necessity against principle here. It is not to claim, fatuously, that we are on occasion faced with "necessary evils," and that we must make the best of the choices we have. The Greeks, on Williams' account, did not see themselves as making the best of a range of difficult choices. Rather, they simply confronted the fact, as they saw it, that their values condemned an institution they could not avoid. Still less do I mean to downplay the danger, on the other side, of mistaking mutable human institutions or natural circumstances as insuperable necessities. The Greeks clearly did so, seeing false necessity in the institutions they knew. If the stance of accepting necessity as fact makes sense, it does so only at the moment of crisis, when the appearance of necessity is challenged at the forefront, both intellectually and practically; and when a return to ordinary principles comes quickly. The sedimentation of necessity into routine is the practical paralIel of the transformation of justification into rationalization.

\footnotetext{
106. WILliams, supra note 1 , at 101, 116-17.

107. ARISTotle, Politics 26 (1252a30) (Benjamin Jowett trans., 1967).

108. WILLIAMS, supra note 1 , at 114. ARISTOTLE, supra note 107, at 26 (1252a33-b5):

For he who can foresee with his mind is by nature intended to be lord and master, and he who can work with his body is a subject, and by nature a slave. . . For [nature] is not niggardly, like the smith who fashions the Delphian knife for many uses; she makes each thing for a single use, and every instrument is best made when intended for one and not for many uses.

109. WILLIAMS, supra note 1 , at 110-12.
} 
Thus, my point is not that the Greeks were right to accept slavery as inevitable, nor that blind acceptance of an injustice is better than a fallaciously justified acceptance. My point (and Williams') is that, given a people who see slavery (or another injustice) as necessary, at least let them see it as a brute and inevitable affront to their principles, not as something their principles can domesticate and make safe to perpetuate. ${ }^{110}$ Let this hypothetical people indeed marshal their principles-as the Greeks did not-in a struggle against the perceived necessary evil, and not work to accommodate it on the level of principle, lest they fall-as Aristotle didinto outright justification. The demand of principle is that we honor it even when we cannot obey it, rather than simply view it as receding under the pressure of other values.

\section{IV}

\section{Macro-Necessity and The Politics of Existence}

As a matter of constitutional principle, the Bybee memo claims that the existential demands of war limit the force of statute. ${ }^{i i}$ As I argued in Part II, the Bybee memo puts forward an argument that ordinary, constitutionally limited politics, understood as congressional regulation of the armed forces, become unconstitutional transgressions of the President's Commander in Chief powers-powers that click into place when a state of war exists. ${ }^{112}$ This I called macro-necessity. I want to argue now for two claims. First, there is a parallel to the Bybee memo's political theory of macro-necessity in the political theory of Carl Schmitt, and this parallel is instructive because the two theories share the same weaknesses and dangers. Second, I argue that the theory of macro-necessity repeats the mistake of micro-necessity, confusing necessity as fact with necessity as justification. By removing politics from the formal legal restraints that legitimate it, the theory of extralegal authority transforms necessity into a device for overriding all rights in the name of the security of a nation whose political identity has perforce been lost.

The OLC lawyers are of course not the first, motivated by political necessity, to argue for a doctrine of emergency powers. Extraordinary legal powers have been part of the constitutional imagination since at least the ancient Roman Constitution, under which the Senate could direct the appointment of a dictator, who would then rule Italy by decree until the

110. This is true even if, as some critics have charged, Williams understates the degree to which "ordinary" Greek thought was infeeted by a less sophisticated version of Aristotle's racism, seeing "barbarians" as naturally fit for slavery. See, e.g., Nick Fisher, Shame and Necessity, 45 ClASSICAL REv. 71 (1995).

111. Bybee memo, supra note 7, at 31-38; see also White Paper, supra note 53, at 3.

112. Bybee memo, supra note 7, at 38 ("In wartime, it is for the President alone to decide what methods to use to best prevail against the enemy."). 
danger had passed. ${ }^{113}$ Although celebrated by Machiavelli and Rousseau, this personal model of emergency rule has generally given way in modern thought to a legalistic model, in which an ordinary office such as the presidency, rather than an individual, is temporarily vested with extraordinary powers, usually by reference to explicit constitutional provisions. ${ }^{114}$ European constitutions, including the French Constitution of 1958 and Italy's Republican Constitution, formalized provisions for states of emergency, while the Anglo-American constitutional tradition has preferred to leave them informal (although traces of such thinking can be seen in the U.S. Constitution's provision for legislative suspension of habeas corpus). ${ }^{115}$ This exception has frequently been noted, and during the Cold War, when a post-nuclear state of emergency was envisioned, conservative political theorist Clinton Rossiter argued for legislation to provide for a Roman-style commissarial dictatorship during times of emergency. ${ }^{116}$

As part of a general theory of broad Executive power, the Bush administration has not sought to make sense of national necessity by changing formal law. As I mentioned above, the chief argument underlying the assertion of the President's supra-statutory authority in times of national emergency is frankly functional: the Constitution is, at bottom, a plan for state survival, and it must be construed to provide the means adequate to survival. ${ }^{117}$ Since, by hypothesis, only supra-statutory Executive authority is sufficient to ensure survival, the Constitution must be read to legitimate this authority. The Constitution, on this view, demands that its own framework of separated and balanced powers be recalibrated during war, to effect a quite different balance, one of "complete" Executive discretion on the battlefield, checked if at all by congressional power over the purse. ${ }^{118} \mathrm{Law}$, which as a conceptual matter

113. John Ferejohn \& Pasquale Pasquino, The Law of the Exception: A Typology of Emergency Powers, 2 lNT'L J. OF Const. L. 210,213 (2004).

114. The Romans in fact had both forms: the dictatorship and the enhanced powers of the consulate. Rousseau and Machiavelli agree that true emergency (but only true emergency) calls for the time-limited dictatorship. Jean JacQues Rousseau, Du Contrat Social 138-40 (Victor Gourevitch ed. and trans., 1997) (1762); Niccolo Machiavelli, Discourses on Livy 84-96 (Julia Conway Bondanella \& Petter Bondanella trans., 1997) (1517); see also Ferejohn and Pasquino, supra note 113, at 213 .

115. 1958 ConST. 16 (Fr.), available at http://www.assemblee-nationale.fr/english/8ab.asp; Cost. Art. 77, cl. 2 (1948) (Italy), available at http://www.oefre.unibe.ch/; U.S. Const. art. 1, § 9, cl. 2. Germany's Basic Law provides for exceptional powers wielded by a Joint Committee in a "State of Defense" (an envisioned invasion by the Soviet Union). GG art. 115 (F.R.G.), available at http://www.iuscomp.org/gla/statutes/GG.htm\#115k.

116. Clinton L. Rossiter, Constitutional Dictatorship: Crisis Government in the MODERN DEMOCRaCies (1948).

117. Bybee memo, supra note 7 , at 36 .

118. Id. at 38. The memo itself refers to no checks on the President's wartime authority, although John Yoo, in his academic identity, does argue for the power of the congressional purse as a sufficient 
aims to provide reasonably determinate criteria demarcating the legitimate from the illegitimate, becomes instead a general imperative that the Executive do what needs to be done. The job of non-constitutional law is essentially to get out of the way of the President's strategic and tactical decision making.

Certainly many Presidents in U.S. history have argued for, and acted upon, a presumption of extra-statutory authority. ${ }^{119}$ The most famous include Jefferson's purchase of the Louisiana Territories, and Lincoln's expansion of the Army and suspension of habeas corpus. Both Presidents justified their acts by reference to public necessity. But, as Jules Lobel and Daniel Farber have argued, both also accepted the authority of the law they broke, making possible post-hoc congressional ratification and opening themselves to the legal consequences should that ratification not be forthcoming. ${ }^{120}$ In one sense, both Presidents justified their use of extrajudicial authority post hoc, by returning to the scene of their crimes, as it were, and looking for ratification. We must therefore be careful to distinguish claims regarding what must be done from what can actually be done under principles of justified authority.

In the Bybee memo (and, arguably, in the White Paper concerning NSA surveillance), the Bush administration took a different tack. Rather than concede the extra-legality of its positions, the OLC put forward a striking constitutional theory of presidential authority, which rendered even very general congressional limitations on intelligence gathering themselves illegal infringements of Executive prerogative. That the Bybee position was phrased in the lawyerly terms of avoiding statutory constructions that raise "constitutional difficulties" should not obscure the "extravagant" (in Richard Posner's word), even radical, wholesale nature of the claim. ${ }^{121}$ Put aside historiographic claims whether this is a plausible interpretation of the Framers' or Ratifiers' views of Executive power. ${ }^{122}$ The roots of the position are theoretical, and are illustrated by the early work of German constitutional theorist Carl Schmitt, who was prompted in response to threats of both right and Ieft radical politics to Weimar's democracy to

check. See John Yoo, Powers of War and Peace: The Constitution and foreign Affairs AFTER 9/1 1 (2006), ch 5, e.g., at 154.

119. Jules Lobel's article, Emergency Power and the Decline of Liberalism, 98 YALE L.J. 1385 (1989), has a useful survey of emergency powers invocations, as does Sanford Levinson, Constitutional Norms in a State of Permanent Emergency, $40 \mathrm{G}_{\mathrm{A}}$. L. REV, 699 (2006).

120. Lobel, supra note 119, at 1392-93; DANiel FARBer, Lincoln's Constitution 192-95 (2003).

121. Bybee memo, supra note 7, at 34; POSNER, Not A SulCIDE PACT, supra note 46, at 68. See also Levinson, supra note 119, at 742-43 (arguing for the radicalism of the Bush administration view of Executive power).

122. Rakove argucs persuasively in Making Foreign Policy, supra note 49, that such a broad view of Executive power clearly postdates ratification, and is instead a product of Alexander Hamilton's controversial view of 1793, voiced in the Helvidus-Pacificus debates, concerning the extent of President Washington's authority to proclaim U.S. neutrality in the European wars. 
undertake an investigation into the relation between states of emergency and political authority. ${ }^{123} \ln$ a debate with the leading lights of German liberalism (notably Hans Kelsen), Schmitt argued for an expansive understanding of the President's emergency authority, as including but not restricted to the particular powers mentioned. ${ }^{124}$

During the 1920s and early 1930s, when Schmitt produced a wideranging theory of politics, law, and legitimacy, the Weimar government functioned substantially under the authority given to the Reich President (then Hindenburg) by Article 48 of the Constitution of $1919 .{ }^{125}$ Article 48 permitted the President to "take the measures necessary to reestablish law and order, if necessary using armed force," and "[i]n the pursuit of this aim," to suspend specified civil rights, notably rights of privacy, free expression, assembly, and security of home. ${ }^{126}$ Thus, according to Schmitt, Article 48 specified the particular civil rights that could be suspended, while enabling all other manner of extra-legal authority. ${ }^{127}$ While Schmitt was mindful of the danger that a dictator charged with returning the state to normal politics might simply perpetuate his own extraordinary rule, he thought the attempt to restrict a dictator through legal forms was both practically mistaken and intellectually dishonest. As a practical matter, a restrictive understanding of the Reich President's emergency powers might prevent him from defeating internal political threats to the republicthreats generated by those who, like the Nazis and the Communists, used the forms of legal process to subvert the constitutional order. As Schmitt colorfully put it, "In the exception the power of real life breaks through the crust of a mechanism that has become torpid by repetition." 128

As a theoretical matter, Schmitt argued that the classically liberal emphasis on the rule of law mistook the real nature of sovereignty, conflating genuine legitimacy, which resides in an Executive's protection

123. Carl Schmitt, Political Theology (George Schwab trans., 1985) (1922). For broader discussion, see Giorgio Agamben, State of Exception (Kevin Attell trans., 2005); Peter C. Caldwell, Controversies over Carl Schmitt: A Review of Recent Literature, 77 J. MODERN HISTORY 357 (2005); Peter C. Caldwell, Popular Sovereignty and the Crisis of German Constirutional LAW (1997). Many writers besides me have been struck by the spirit of Schmitt in contemporary Executive politics. See, e.g., Levinson, supra note 119, at 744; Slavoj Zizek, Are we in a war? Do we have an enemy?, 24 London Rev. Books (May 23, 2002); William E. Scheuerman, Carl Schmitt and the Road to Abu Ghraib, 13 Constellations 108 (2006).

124. SCHMITT, LEGALITY AND LEGITIMACY, supra note 11.

125. This history is summarized by AGAMBEN, supra note 123, at 14-16.

126. Weimar Const. of 1919, Art. 48: "In case public safety is seriously threatened or disturbed, the Reich President may take the measures necessary to reestablish law and order, if necessary using armed force. In the pursuit of this aim he may suspend the civil rights described in articles $114,115,117,118,123,124$ and 154, partially or entirely." Available at http://www.zum.de/psm/weimar/weimar_vve.php.

127. Schmitr, Legality AND Legitimacy, supra note 11, at 68-74; see also the helpful introduction by John P. McCormick, pp. xxxvi-xxxix.

128. Schmitt, Political Theology, supra note 123, at 15. 
of the will and real interests of a people, with formal legality. According to Schmitt, law is a system of governance designed to cope with specific circumstances-not, fundamentally, a system of normative authority, as in Kelsen's view. ${ }^{129}$ Necessarily, law will encounter legally ungovernable situations, and those situations will demand action by someone in a position to act. The key claim for Schmitt is that this practical demand for decision and action itself imparts authority, as shown by the popular acceptance of emergency rule. Put another way, actual political authority shows that authority is logically prior to law. Thus Schmitt's most famous pronouncement: "Sovereign is he who decides on the exception."130 Real political authority lies with him who can suspend the law, not with him bound to it. Or, using the tag of Hobbes that Schmitt takes as his leitmotif: auctoritas, non veritas fecit legem. Authority, not truth, makes law. ${ }^{131}$

For Schmitt, the claim that sovereignty consists essentially in the power to rule beyond law captures the core of a broader theory that can be called existential politics. Existential politics means making central the concepts of order and national identity, and making peripheral the formal processes of legislation and administration. This model of politics is seen in Schmitt's other famous aphorism that "The specific political distinction to which political actions and motives can be reduced is that between friend and enemy." 132 According to Schmitt, just as aesthetics can be summarized in terms of developing criteria for distinguishing the beautiful from the ugly, or economics the profitable from the unprofitable, so politics consists in making and deploying a distinction between "friends," or co-members of the unified state, and its "enemies," or those with whom the state is in actual or potential conflict. ${ }^{133}$ But unlike aesthetics or economics, whose distinctions follow on independent characteristics of the objects in their domain, political action itself contributes the characterizations as friend or enemy. Schmitt writes that the friend-enemy distinction is independent of any other distinctions, moral or factual. Prior to governance, friendship and enmity (or peace and war) are fluid, depending on mutable affinities and coalitions. Politics gives sharp borders to those concepts. Politics is "existential," both in that it serves as the basic logical principle of identity - and therefore of conflict-in the world, and in that it serves as the very real condition of physical survival or death.

Existential politics is Hobbesian politics, seeing everything through the lens of conflict. In the absence of politics there is only individualized

\footnotetext{
129. See Hans Kelsen, The Pure Theory of Law (Max Knight trans., 1967) (1934).

130. Schmitt, Political Theology, supra note 123 , at 5.

131. Id. at 33 .

132. Carl Schmitt, The Concept of the Political 26 (George Schwab trans., 1996) (1932).

133. Id. at $26-28$
} 
conflict; politics renders conflict collective by monopolizing force within the collective (thus making "friends") and holding the potential enemies of the collective at sword's point. Maintaining order by policing the friendenemy line is therefore the central task of political authorities, the condition of all "ordinary" political processes. Since law is a product of ordinary politics, order is also the condition of law. And since the Executive's task is to create order, its sovereign authority must thereby transcend law, deciding when ordinary politics can take place and when instead it must be accepted. Legitimacy resides in a people's acquiescence, understood as nonresistance, to the concrete problem-solving capacities of "administrative" political authority, and while Schmitt maintained that Executive authority in contexts of emergency was "democratic," this amounts largely to asserting a plebiscitary basis through popular acclamation. ${ }^{134}$ In principle, Executive decision making is meant to be constrained by respect for what Schmitt termed the "concrete orders" of society - the organic, deep social structure provided principally by religious and civil institutions. ${ }^{135}$ On this view, legitimacy is partly functional, or "decisional," and partly organic. But since structural separation of powers is a key instance of the misguided emphasis on legalism that both obscures real political agency and prevents state responses to genuine existential threats, only the Executive determines what these concrete orders demand.

In our current context, however, Schmitt's eventual embrace of fascism, ${ }^{136}$ through the vehicle of a myth of a Iegitimating popular spirit, is less interesting than the basic move of relocating legitimacy to the space before law. For in their common emphasis on the existential demands of order and the need for swift response, there are clear connections between Schmitt's theory of existential politics and the Bybee memo's macro-

134. SChMitt, Legality AND LegitimaCy, supra note 11 , at 28,60 . In later work, especially Schmitt's controversial interpretation of Hobbes, Schmitt argues that the sovereign is not a creator of national identity out of chaos, but rather forms a post-national eultural identity out of pre-national cultural materials. Thus, in his view, Hobbesian "liberalism," which pretends to be culturally neutral for the sake of preserving life, actually makes its own cultural stand. For discussion, see Victoria Kahn, Hamlet or Hecuba: Carl Schmitt's Decision, 83 RePRESENTATIONS 67 (2003).

135. Carl Schmitt, On The Three Types of Juristic Thought (Joseph W. Bendersky ed. and trans., 2004) (1934).

136. Schmitt's concept of sovereignty as decisional, but rooted in pre-legal ordering, reflects his longstanding cultural and political conservativism. But Schmitt's increased emphasis on this concept coincides both with his joining of the Nazi party and with the Nazis' claim to root their authority not just in response to Weimar's chaos (inflicted by themselves), but in their capacity to represent and defend real Germanness. There is a lively debate whether Schmitt's move reflects intellectual conservativism as much as political opportunism. Certainly he offered the Nazis a theoretical grounding they could, and did, make use of. Schmitt also became a prominent anti-Semite, in both writing and deed, for example purging academic ranks of Jewish scholars. As with Martin Heidegger, there is also considerable debate whether Schmitt was merely a deplorable opportunist or a sincere Nazi. See Caldwell, Controversies over Carl Schmitt, supra note 123. 
necessity justifications for Executive overrides of legislative authority. ${ }^{137}$ Like Schmitt, the Bush administration sees national security in time of attack as providing a sufficient justification for expanded, extra-statutory Executive authority, governed by the broad mandate of a constitutional charge to respond swiftly and flexibly to enemies of the state, unconstrained in tactics by than the legalistic regulation of the legislature. The Bybee memo's broad reading of the Commander in Chief power and its reluctance to seek specific legal authority for its acts are precisely Schmittian in their view of legal forms as inimical to national needs. ${ }^{138}$ Most importantly, the administration's theory of wartime Executive power echoes the errors of Schmitt's argument. Indeed, it deepens those errors by extending the argument from national survival to national security.

Hobbes, like Schmitt, saw an evident truth: without order there can be no politics. As a logical matter, the first question about political authority is whether it is effective in securing order. At the limit, when total disorder or other forms of political extinction become real possibilities, then the only task for political authorities is to preserve or reconstitute order. The question, however, is what follows from this point. For Schmitt, what followed was a claim about the essence of politics, not about the conditions of its possibility. Politics, viewed clearly enough, is nothing other than the work of order; and the identity of a given state is just a reflection of that order. But this is surely a mistake. In ordinary times, when order persists, the essence of politics is familiar: allocating scarce resources, administering projects and personnel, and securing justice. Schmitt's radicalism lies in seeing that ordinary political activity as basically epiphenomenal, whereas real politics involves the existential decisions of the Executive, or the cultural work of social institutions. Ordinary politics, the bread and butter of legislative supremacy, becomes degraded, in Schmitt's view, as a deracinated technocracy; and, in the modern view, as a market for legislative favors. ${ }^{139}$

137. Note that $\mathbf{I}$ am not claiming that Bush administration policy deliberately reflects Schmitt's theories. While some of the administration's Executivc power theorists may have had some acquaintance with Schmitt, and certainly with Schmitt's colleague, Leo Strauss (who also saw Hobbes as one of the preeminent political theorists), there is no reason to suppose any direct derivation from his views.

138. There are other striking parallels to Schmitt's thought. First is the "theological" aspcct of Schmitt's conception of politics, that political decisions and judgments by the Executive are to be accepted as revelations, not as arguments, so that differences in politics become, in effect, differences in faith. Compare this with (a) Ron Suskind's interview with administration officials on the distinction between outsiders in the "reality-based community," versus administration members who "make our own reality," and (b) with Bush's famous pronounccment, "you are either with us or with the terrorists." Second is the administration's view (echoed by Yoo) that the 2004 election was, in effect, a popular ratification of the strong Executive theory.

139. Schmitt, Political Theology, supra note 123, at 65 . This view of the legislative process is implicit in official arguments for Executive suprcmacy, but it is highly visible in contemporary work in positive political theory, and in the normative lessons drawn therefrom, as in Judge Easterbrook's 
Displacing politics so is a mistake. Under conditions of cultural and ideological pluralism, ordinary politics is the vehicle through which a political community determines and expresses its identity and its commitments, its conception of social justice and collective ambition. Just because that identity can be threatened by war does not mean that it does not have content independent of the conditions of existence. Today, any Executive claim to legitimacy in organic cultural order would smack of fascism. Of course, in a post-9/11 world, claims of national security cannot be dismissed airily. But to collapse the notion of legitimacy in times of war, or perceived emergency, into pure functionalism is to fall prey to the pure decisionism that Schmitt himself tried to avoid. It creates a category of "nation" without content, simply as a placeholder for whatever the Executive seeks to keep in power. The existential conception of politics, in other words, fails to see the essence of ordinary life outside the friendenemy struggle, that the relations of friends themselves has a discernible character and a history that matters; and that diplomatic détente with one's enemies can define a long-term relation as much as can open war.

The Bybee memo's parallel mistake is to conceive "national security" in vacuous terms, as the target of Executive action, without respect for the content of the political identity whose safety must be assured. When hijacked jets strike our towers and kill our citizens, or when roadside bombs and ambushes kill our soldiers, there is of course real suffering, real death. But, genuinely terrible as these things are, it would be an exaggeration to say that the security of the nation is threatened when even some thousands of its members are killed. The vulnerability of the people cannot be equated with the vulnerability of the nation itself. Instead, the nation is rendered insecure only when its identity and existence comes under siege. The Civil War posed a threat of literal dissolution of the state. Many other nations have also faced (and succumbed to) genuine existential threats, sometimes for the better for their people, sometimes for the worse. Thus, the assessment of Lincoln's unilateral suspension of habeas corpus comes far closer (if not passes) the bar of real constitutional necessity. ${ }^{140}$ Were al Qaeda to get ahold of a dirty bomb, it might render a city uninhabitable and wreak huge economic devastation. That said, 1 know of no one who actually believes the existence of the nation itself is under siege. Our hard-won principles concerning humane treatment of our enemies have confronted graver threats in the past, in the global wars we have faced, not to mention the threat of nuclear annihilation that hung over

influential theory that statutes ought to be interpreted as arms-length deals between self-interested parties. See Frank H. Easterhrook, Statutes' Domains, 50 U. CHI. L. Rev. 533 (1983). For an overview of these issues and references to much of the current literature, see WiLliam N. EsKridge, Philip P. Frickey \& Elizabeth Garrett, Legislation and Statutory Interpretation (2006), eh 3.

140. See FARBER, supra note 120, at 115-43. 
the nation for more than three decades. Al Qaeda may be a new adversary, presenting a distinct threat and calling for adjustments at the margin in our scheme of civil liberties. But the case is not yet made that we face real, existential necessity, forcing us to put aside for the duration the principles embedded in our domestic and international law.

Perhaps it is not too overwrought to worry instead that the real existential threat comes from the evisceration of our principles in the name of security. This is the second error: Schmitt's failure to distinguish between recognizing the limits of constitutionalism and subordinating it to exigency. Legal and political theorists of very different political stripes have recognized that constitutions are made for normal times, and that the ordinary processes and balances they require may make impossible a rapid response to acute threats to the existence of a state. ${ }^{141}$ In situations of genuine crisis, as Rousseau wrote, it would be wrong "to consolidate political institutions to the point of depriving oneself of the power to suspend their effect." 142 The question is what to do about this point. One possibility is to treat constitutional structure as a heuristic, a rough and ready guide to ordinary political effectiveness, to be suspended when circumstances indicate that the guidance of the rule is unlikely to be optimal. ${ }^{143}$ This is, in effect, what constitutionalism became in Weimar, as continuous states of emergency led to governance almost entirely under the aegis of Article 48. This is constitutionalism as non-constitutionalism, whereby Schmitt's aphorism about sovereignty can become self-fulfilling prophecy, the exception swallowing law. The weakness of the heuristic model precisely mirrors the weaknesses of utilitarianism in moral thought: all distinctive values, for example political rights against tyrannical domination, or moral rights against torture, are subsumed by a general value of welfare. The rules that ordinarily serve as vehicles for those values may become so riddled by exception that the values themselves are lost.

It is not hard to come by alternatives to heuristic constitutionalism, though there is much debate concerning the optimal choice for emergency measures: whether formal or informal provision for emergency, in what ways the temporary character of the provision should be ensured, and so forth. Bruce Ackerman's proposal for a constitutional "escalator,"

141. The conservative view for the need for a constrained Executive is discussed in Rossiter, Constitutional Dictatorship. For a prominent example of such recognition by avowedly liberal constitutionalists, and suggestions for coping in a structural way with emergency, see Bruce Ackerman, The Emergency Constitution, 113 YaLE L.J. 1029 (2004); Cass Sunstein, Minimalism at War, 47 Sup. CT. REv. 48 (2004). For valuable discussion to which 1 am much indebted, see David Dyzenhaus, Schmitt v. Dicey: Are States of Emergency Inside or Outside the Legal Order?, 27 CaRdozo L. REv. 2005 (2006).

142. RouSSEAU, supra note 114 , at 138 .

143. This is, roughly, the position staked out by Posner in Not A SuICIDE PACT, supra note 46. 
requiring ever-greater majorities for ever longer incursions into ordinary rights, is one possibility. ${ }^{144}$ What is beyond controversy is Rousseau's next point, that "only the greatest dangers can counterbalance the danger of disturbing the public order, and one should never suspend the sacred power of the laws except when the salvation of the fatherland is at stake." "145 What therefore is most important, as a matter of institutional design, is to create institutions to repel claims of constitutional necessity, not to accommodate them. It does no dishonor to a principled commitment against torture to recognize its limits in the hypothetical of the ticking bomb. Nor do we dishonor a general commitment to life's value by insisting that the hypothetical is imaginary, that we remain outside the state of emergency until we can no longer resist its existential claim. Similarly, we do not dishonor our constitutional system, our structured system of sovereign legitimacy, to recognize its limits in extremis. We would only dishonor it by entering too quickly into the feverishly imagined state of national emergency and accepting too easily the claims of necessity and the exigencies of national security. ${ }^{146}$ The Hobbesian moment, when order must be beaten out of chaos, must be confronted only as necessity as fact, not as a rolling justification for Executive supremacy.

\section{Conclusion}

I have argued that the attempt to justify both torture and extra-legal authority by reference to necessity fails. It rests upon a conflation of necessity as fact with necessity as justification and on a broad and deep misunderstanding of the nature of pre-institutional rights.

The bedrock principles we have, concerning the dignity of humanity and the limits of legitimate power, are hard-won achievements of the last several centuries. Scrabbled together out of convention, claimed in the shadow of authoritarian power, they have become the marks by which we know our moral identities as both persons and nations. Threats and emergencies demand response, but that response must be grounded in a confidence in our principles' abilities to meet the demands of the world on our own terms. This confidence is equally a form of judgment: the determination that threats to our interests not be confused with threats to our existence. Far more dangerous to us, to who we are, is the threat of finding necessity in every conflict with evil and emergency in every war.

144. Ackerman, supra note 141, at 1047-49.

145. Rousseau, supra note 114 , at 138 .

146. It would equally be a mistake to pay no heed to the powerful psychological dimension of the ticking-bomb and national-emergency hypotheticals. The fantasies of being the leader on the white horse, the secret agent saving the city, are surely as tempting to those in power as they are to the Hollywood imagination. 
At the level of philosophical reflection, the ticking-bomb example does show something. It shows that we can imagine limits to even our most deeply held moral principles. But we should use this realization to strengthen our principles and their application in the world, not to abridge them. Here is how the realization of imagined limits can strengthen principles such as the right against torture. By their very divergence from real situations (existential necessity can exist only in a hypothetical world), imagined scenarios like the ticking-bomb example can continually remind us that we have not reached the imagined limits in reality, that we need to push our principles further and ever further, that if we relinquish our deepest precepts in an ideal world of imagined scenarios, there will surely be no hope for them in the real world we all inhabit. 